Prepared in collaboration with the Door County Soil and Water Conservation Department and University of Wisconsin-Oshkosh

\title{
Evaluation of Potential Sources and Transport Mechanisms of Fecal Indicator Bacteria to Beach Water, Murphy Park Beach, Door County, Wisconsin
}
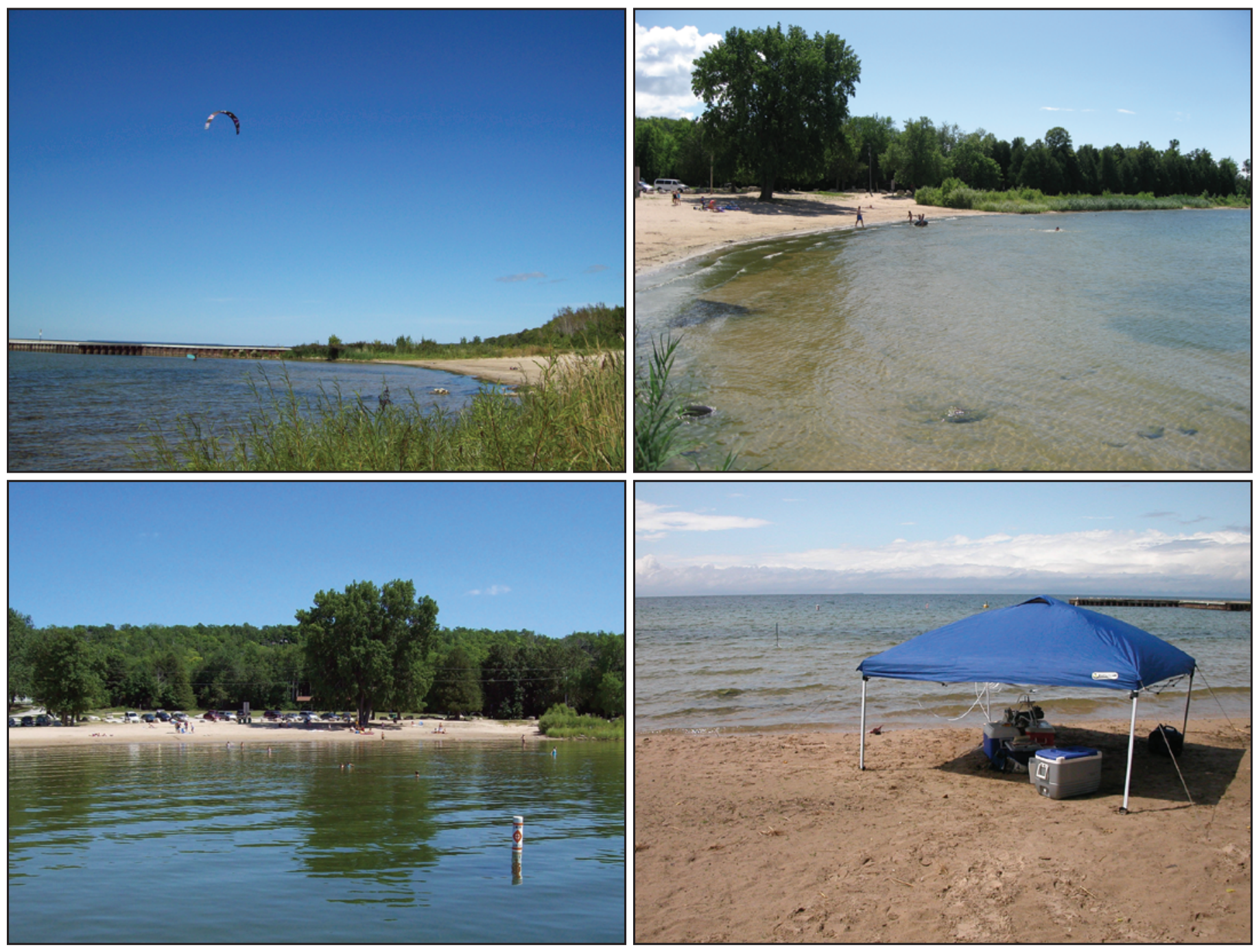

Scientific Investigations Report 2012-5190

U.S. Department of the Interior U.S. Geological Survey

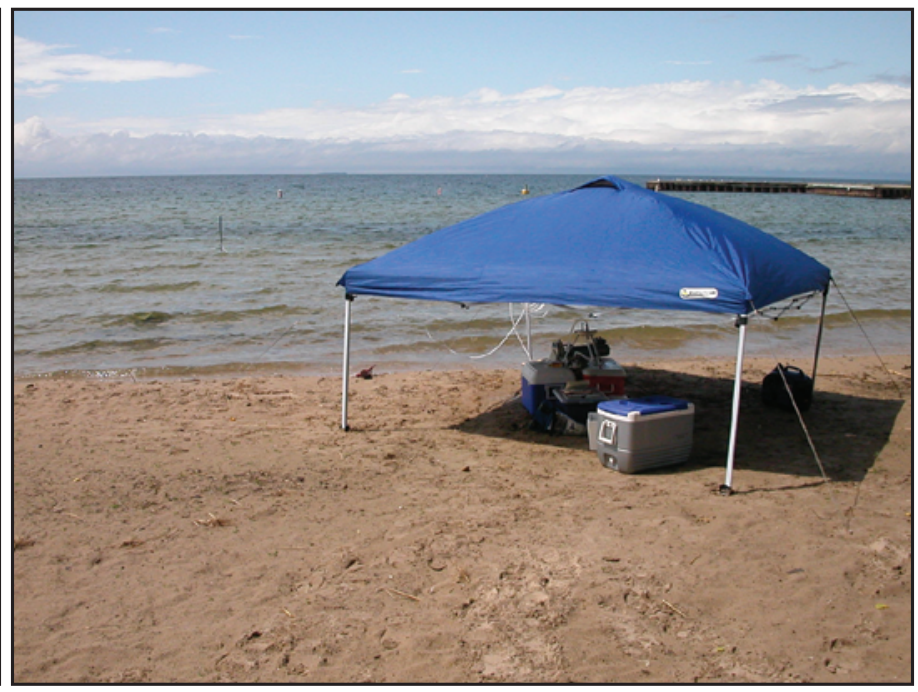




\section{Cover images:}

Upper left: Murphy Park Beach looking north, August 7, 2008. (Photograph by Charles Dunning, U.S. Geological Survey (USGS))

Upper right: Murphy Park Beach looking south, August 7, 2008. (Photograph by Charles Dunning, USGS)

Lower left: Murphy Park Beach looking east from the pier, July 23, 2008. (Photograph by Charles Dunning, USGS)

Lower right: Suspended particulate sampling equipment used at Murphy Park Beach. Photograph is from the beach looking west, August 25, 2009. (Photograph by Jason Smith, USGS) 


\section{Evaluation of Potential Sources and Transport Mechanisms of Fecal Indicator Bacteria to Beach Water, Murphy Park Beach, Door County, Wisconsin}

By Paul F. Juckem, Steven R. Corsi, Colleen McDermott, Gregory Kleinheinz, Lisa R. Fogarty, Sheridan K. Haack, and Heather E. Johnson

Prepared in collaboration with the Door County Soil and Water Conservation Department and University of Wisconsin-0shkosh

Scientific Investigations Report 2012-5190 


\section{U.S. Department of the Interior \\ KEN SALAZAR, Secretary}

\section{U.S. Geological Survey Marcia K. McNutt, Director}

U.S. Geological Survey, Reston, Virginia: 2013

For more information on the USGS - the Federal source for science about the Earth, its natural and living resources, natural hazards, and the environment, visit http://www.usgs.gov or call 1-888-ASK-USGS.

For an overview of USGS information products, including maps, imagery, and publications, visit http://www.usgs.gov/pubprod

To order this and other USGS information products, visit http://store.usgs.gov

Any use of trade, firm, or product names is for descriptive purposes only and does not imply endorsement by the U.S. Government.

Although this information product, for the most part, is in the public domain, it also may contain copyrighted materials as noted in the text. Permission to reproduce copyrighted items must be secured from the copyright owner.

Suggested citation:

Juckem, P.F., Corsi, S.R., McDermott, Colleen, Kleinheinz, Gregory, Fogarty, L.R., Haack, S.K., and Johnson, H.E., 2013, Evaluation of potential sources and transport mechanisms of fecal indicator bacteria to beach water, Murphy Park Beach, Door County, Wisconsin: U.S. Geological Survey Scientific Investigations Report 2012-5190, 29 p. 


\section{Acknowledgments}

\section{Local Project Coordinators}

Amanda Surfus, Door County Soil and Water Conservation Department, Sturgeon Bay, Wis.

William Schuster, Door County Soil and Water Conservation Department, Sturgeon Bay, Wis.

\section{Data Collection and Analysis}

Nathan Frohn, UW-Oshkosh, collected all of the fecal indicator bacteria samples, except particulate-associated samples, and ancillary data in 2009.

Austin Baldwin and Jason Smith, U.S. Geological Survey, Middleton, Wis., collected particulateassociated fecal indicator bacteria samples.

The National Oceanic and Atmospheric Administration, Great Lakes Environmental Research Laboratory, Ann Arbor, Mich., supplied results from the Great Lakes Coastal Forecasting System.

\section{Publishing Support}

Laura Nelson, Office Assistant, U.S. Geological Survey Wisconsin Water Science Center, Middleton, Wis.

Michelle Greenwood, Reports Specialist, U.S. Geological Survey Wisconsin Water Science Center, Middleton, Wis.

Bonnie Stich, Editor, U.S. Geological Survey Science Publishing Network, Louisville, Ky.

\section{Technical Reviewers}

Robert Waschbush, U.S. Geological Survey, Wisconsin Water Science Center, Middleton, Wis.

Marlene Noble, U.S. Geological Survey, Pacific Southwest Area, Menlo Park, Calif.

\section{Editorial Reviewer}

Elizabeth Ciganovich, Technical Writer-Editor, U.S. Geological Survey Science Publishing Network, Madison, Wis.

\section{Approving Official}

Kevin Breen, Bureau Approving Official, U.S. Geological Survey Office of Science Quality and Integrity, New Cumberland, Pa. 


\section{Contents}

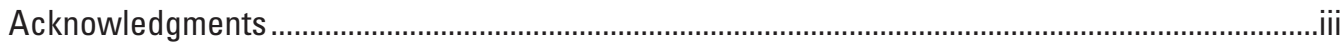

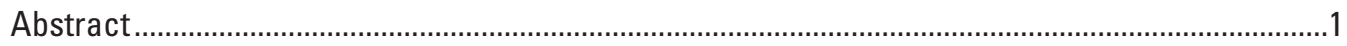

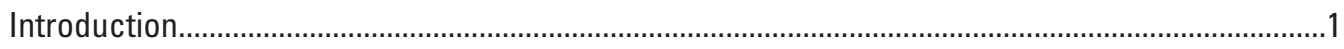

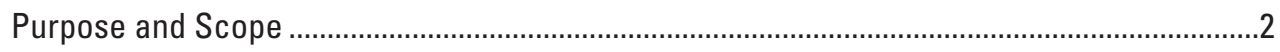

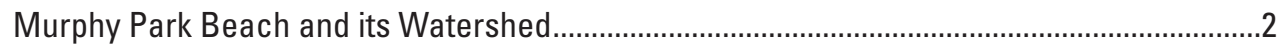

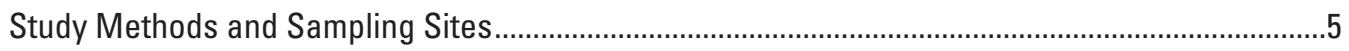

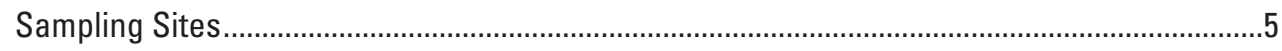

Sampling Schedule ....................................................................................................

Lake Water Sampling ......................................................................................................

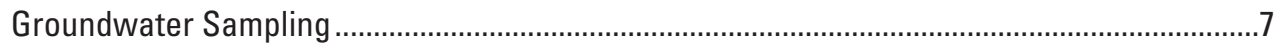

Suspended Particulates in Lake Water.................................................................................

Sand Sampling..............................................................................................................

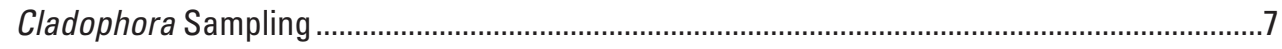

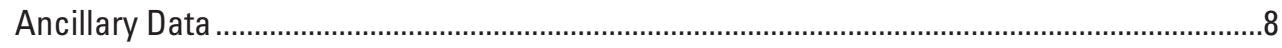

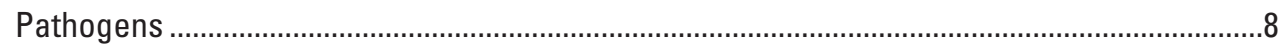

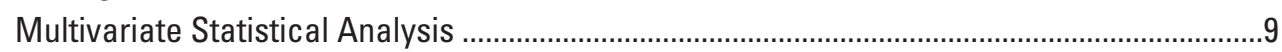

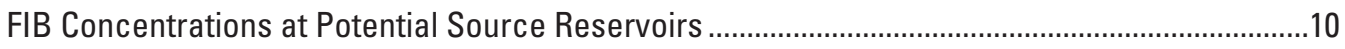

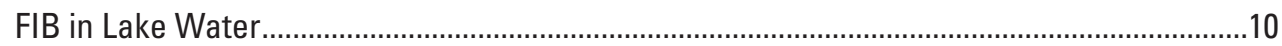

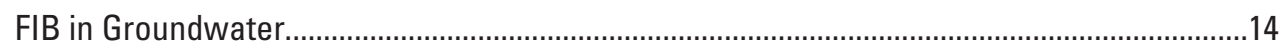

FIB Associated with Suspended Particulates in Lake Water................................................16

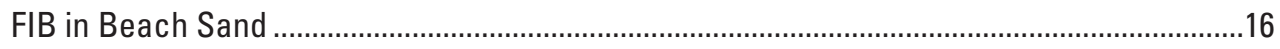

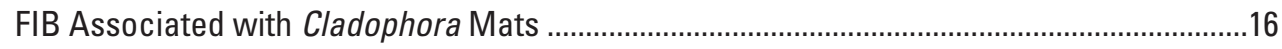

Pathogen Detection in Lake Water and Groundwater ................................................................16

Multivariate Analysis of Escherichia coli (E. coli) Concentrations ................................................20

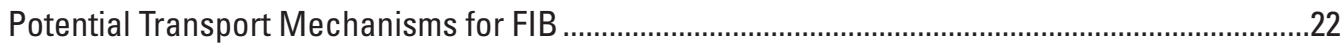

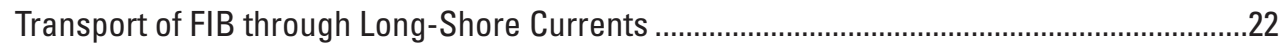

Transport of FIB from Swash-Zone Groundwater ..............................................................2

Transport of FIB from Sand and Cladophora due to Storm Activity ........................................24

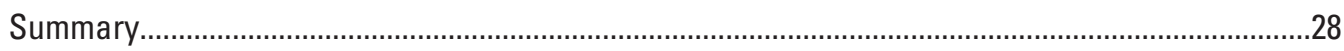

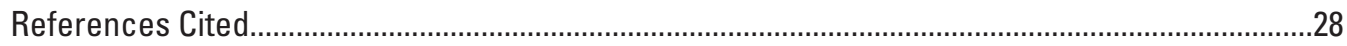

\section{Figures}

1. Map showing the location of Murphy Park Beach and watershed in Door County, Wisconsin

2. Maps showing the locations of data-collection sites at Murphy Park Beach, 2008-9

3. Boxplots of $A, E$. coli and $B$, enterococci concentrations in lake water and ratios of $C, E$. coli and $D$, enterococci for lake water sites at Murphy Park Beach, 2008-9 
4. Graphs showing time series of $A, E$. coli and $B$, enterococci concentrations in lake water at Murphy Park Beach, 2008-9

5. Boxplots of $A, E$. coli and $B$, enterococci concentrations and ratios of $C$, E. coli and $D$, enterococci in groundwater for piezometer (PZ) sites at Murphy Park Beach, 2008-9.

6. Boxplots of $A, E$. coli and $B$, enterococci concentrations and ratios of $C$, E. coli and $D$, enterococci in samples for suspended particulates at Murphy Park Beach, 2009

7. Boxplots of $A, E$. coli and $B$, enterococci concentrations in sand at Murphy Park Beach, 2009

8. Boxplots of $A, E$. coli and $B$, enterococci concentrations and ratios of $C, E$. coli and $D$, enterococci in water within and adjacent to Cladophora mats and in beach water at Murphy Park Beach, 2009

9. Boxplot of $E$. coli concentration in beach water at Murphy Park Beach, 2009, grouped by specific conductance and wave height

10. Rose diagram showing $E$. coli and enterococci concentrations with respect to $A$, lake water current direction and $B$, wind direction at the time of lake water-sample collection at the beach water site at Murphy Park Beach, 2009..

11. Schematic cross section showing groundwater recharge and discharge as a mechanism for transporting fecal indicator bacteria from the swash-zone groundwater reservoir into the lake water column.....

12. Graphs showing $A, E$. coli and $B$, enterococci concentrations in beach water and in water samples collected within and adjacent to Cladophora mats at Murphy Park Beach, 2009

13. Graphs showing E. coli concentrations associated with relative abundance of Cladophora at the time of sampling $A$, for the 2008-9 study period and for 2009 categorized by $B$, wave height, $C$, turbidity, $D$, current speed, and $E$, wind speed at the beach water site, Murphy Park Beach

\section{Tables}

1. Dates, locations, and types of environmental samples collected at Murphy Park Beach, 2008-9.

2. Growth medium and enrichment parameters for target pathogenic bacteria...................8

3. Positive controls and detection limits for polymerase chain reaction (PCR) assays .......9

4. Variables used in multivariate regression for $E$. coli concentrations at Murphy Park Beach, July-September 2009.

5. Fecal indicator bacteria concentrations in samples from the lake water sampling sites and current directions at the three lake water sampling sites at Murphy Park Beach, 2008-9. 


\section{Conversion Factors, Abbreviations, and Abbreviated Water- Quality Units}

\begin{tabular}{|c|c|c|}
\hline Multiply & By & To obtain \\
\hline \multicolumn{3}{|c|}{ Length } \\
\hline foot $(\mathrm{ft})$ & 0.3048 & meter $(\mathrm{m})$ \\
\hline mile (mi) & 1.609 & kilometer $(\mathrm{km})$ \\
\hline \multicolumn{3}{|c|}{ Area } \\
\hline acre & 4,047 & square meter $\left(\mathrm{m}^{2}\right)$ \\
\hline square mile $\left(\mathrm{mi}^{2}\right)$ & 2.590 & square kilometer $\left(\mathrm{km}^{2}\right)$ \\
\hline \multicolumn{3}{|c|}{ Volume } \\
\hline gallon (gal) & 3.785 & liter $(\mathrm{L})$ \\
\hline gallon (gal) & 3,785 & milliliter $(\mathrm{mL})$ \\
\hline gallon (gal) & $3,785,000$ & microliter $(\mu \mathrm{L})$ \\
\hline \multicolumn{3}{|c|}{ Flow rate } \\
\hline mile per hour $(\mathrm{mi} / \mathrm{h})$ & 1.609 & kilometer per hour $(\mathrm{km} / \mathrm{h})$ \\
\hline \multicolumn{3}{|c|}{ Mass } \\
\hline ounce, avoirdupois (oz) & 28.35 & $\operatorname{gram}(\mathrm{g})$ \\
\hline ounce, avoirdupois (oz) & $28,350,000,000$ & nanogram (g) \\
\hline
\end{tabular}

Temperature in degrees Celsius $\left({ }^{\circ} \mathrm{C}\right)$ may be converted to degrees Fahrenheit $\left({ }^{\circ} \mathrm{F}\right)$ as follows:

${ }^{\circ} \mathrm{F}=\left(1.8 x^{\circ} \mathrm{C}\right)+32$

Specific conductance is given in microsiemens per centimeter at 25 degrees Celsius $(\mu \mathrm{S} / \mathrm{cm}$ at $\left.25^{\circ} \mathrm{C}\right)$.

Turbidity is given in Nephelometric Turbidity Units (NTU).

Concentrations of chemical constituents in water are given either in milligrams per liter (mg/L) or micrograms per liter $(\mu \mathrm{g} / \mathrm{L})$.

Concentrations of Fecal Indicator Bacteria (FIB) from grab samples of water are given as most probable number per 100 milliliters of water (MPN/100mL).

Concentrations of FIB from sand samples are given as most probable number per gram of dry sand (MPN/g). 


\title{
Evaluation of Potential Sources and Transport Mechanisms of Fecal Indicator Bacteria to Beach Water, Murphy Park Beach, Door County, Wisconsin
}

\author{
By Paul F. Juckem, ${ }^{1}$ Steven R. Corsi, ${ }^{1}$ Colleen McDermott, ${ }^{2}$ Gregory Kleinheinz, ${ }^{2}$ Lisa R. Fogarty, ${ }^{1}$ \\ Sheridan K. Haack, ${ }^{1}$ and Heather E. Johnson' ${ }^{1}$
}

\section{Abstract}

Fecal Indicator Bacteria (FIB) concentrations in beach water have been used for many years as a criterion for closing beaches due to potential health concerns. Yet, current understanding of sources and transport mechanisms that drive FIB occurrence remains insufficient for accurate prediction of closures at many beaches. Murphy Park Beach, a relatively pristine beach on Green Bay in Door County, Wis., was selected for a study to evaluate FIB sources and transport mechanisms. Although the relatively pristine nature of the beach yielded no detection of pathogenic bacterial genes and relatively low FIB concentrations during the study period compared with other Great Lakes Beaches, its selection limited the number of confounding FIB sources and associated transport mechanisms.

The primary sources of FIB appear to be internal to the beach rather than external sources such as rivers, storm sewer outfalls, and industrial discharges. Three potential FIB sources were identified: sand, swash-zone groundwater, and Cladophora mats. Modest correlations between FIB concentrations in these potential source reservoirs and FIB concentrations at the beach from the same day illustrate the importance of understanding transport mechanisms between FIB sources and the water column. One likely mechanism for transport and dispersion of FIB from sand and Cladophora sources appears to be agitation of Cladophora mats and erosion of beach sand due to storm activity, as inferred from storm indicators including turbidity, wave height, current speed, wind speed, sky visibility, 24-hour precipitation, and suspended particulate concentration. FIB concentrations in beach water had a statistically significant relation ( $p$-value $<0.05$ ) with the magnitude of these storm indicators. In addition, transport of FIB in swash-zone groundwater into beach water appears to be driven by groundwater recharge associated with multiday precipitation and corresponding increased swash-zone groundwater discharge at the beach, as indicated by an increase in the specific conductance of beach water. Understanding the dynamics of FIB sources (sand, swash-zone groundwater, and Cladophora) and transport mechanisms (dispersion and erosion from storm energy, and swash-zone groundwater discharge) is important for improving predictions of potential health risks from FIB in beach water.

\section{Introduction}

Fecal indicator bacteria (FIB) monitoring results are often used to assess water quality at recreational beaches for protection of human health. The choice of Escherichia coli (E. coli) for freshwater assessment was based on epidemiological studies that have identified an association of $E$. coli with gastrointestinal illness (Dufour, 1984). Current water-quality criteria for fresh recreational waters are based on this information. More recently, epidemiological research has identified a relation of gastrointestinal illness to enterococci as measured using quantitative polymerase chain reaction (PCR) techniques (Wade and others, 2006). Additional research has also identified increased risk for skin illnesses with increased concentrations of enterococci (Fleisher and others, 2010).

FIB in recreational waters can originate from many sources. Some of the primary sources include streams and storm sewers that discharge point and nonpoint contamination near beaches, overland runoff, fecal matter from birds, groundwater discharges, beach sand, algae such as Cladophora (Byappanahalli and others, 2003; Englebert and others, 2008; Vanden Heuvel and others, 2010), wastewater effluents, and resuspension from lake sediments and the swash zone (Lee and others, 2006). At beaches that have periodic contamination where a dominant source is not obvious, a comprehensive approach is warranted to understand influences on the water quality.

${ }^{1}$ U.S. Geological Survey.

${ }^{2}$ University of Wisconsin-Oshkosh. 
Door County, Wis. is a unique setting in the Great Lakes region from a geographic, geologic, social, and economic standpoint. Door County is located on a peninsula between Green Bay and Lake Michigan and has many public beaches. A large portion of the economy is based on tourism, and recreational beaches are an important attraction for tourists in Door County. The subsurface geology is dominated by fractured carbonate rock aquifers that have a high horizontal to vertical anisotropy and low bulk porosity, which results in rapid horizontal transport of water through the shallow groundwater system (Sherrill, 1978).

Frank Murphy Park Beach in Door County (Murphy Park Beach) was chosen for this study by the U.S. Geological Survey, in collaboration with the Door County Soil and Water Conservation Department and University of Wisconsin-Oshkosh, because it (1) is a relatively pristine beach compared with other Great Lakes beaches that have been intensively studied, but it also has experienced periodic FIB exceedances during the summer, (2) has a relatively well-defined extent, (3) does not have a substantial surface water tributary nearby, and (4) experiences relatively large groundwater discharge along the beach during the spring, which at times seeps to the land surface on the beach and drains into the swimming area. The groundwater typically has relatively low concentrations of FIB and only periodically has elevated concentrations of E. coli; 5 percent of E. coli samples had greater than 235 most probable number per 100 milliliters of water (MPN/100mL) from 2003 to 2007 (Door County Soil and Water Conservation Department, 2008).

Several research efforts have evaluated Murphy Park Beach for factors associated with potential FIB contamination. Rainfall has been shown to have short-term effects on E. coli concentrations, which are significant 3 hours (hr) after rainfall, but not after $8 \mathrm{hr}$ (Kleinheinz and others, 2009). Bird waste was shown to influence $E$. coli concentration on the day following deposition (Kleinheinz, McDermott, and Chomeau, 2006). Water samples collected within and outside of Cladophora mats revealed that the average concentrations of $E$. coli were greatest within the mats and that concentrations decreased with distance from the mat up to 33 feet (ft) (Englebert and others, 2008). In addition, sand has been identified as a source of $E$. coli contamination in nearby beaches, and swash zone sand typically has greater $E$. coli concentrations than upshore sand (Zehms and others, 2008).

\section{Purpose and Scope}

This report describes the methods and results of an evaluation of multiple potential influences of FIB occurrence, including sources and transport mechanisms to the water column, at a relatively pristine beach on the shore of Green Bay in Door County, Wis. Pathogenic bacteria occurrence was also evaluated as part of this study, but sources and transport mechanisms for pathogens were not evaluated because no pathogenic genes were detected. The field investigation for the study described in this report included surface and groundwater sampling during August-September 2008 and July-August 2009.

\section{Murphy Park Beach and its Watershed}

Murphy Park Beach is located in a small embayment on the eastern side of Green Bay (the western shore of Door County), 50 miles (mi) north of the City of Green Bay (fig. 1) and 12 mi north of the City of Sturgeon Bay. Door County is entirely within the Door Peninsula, which begins in northern Brown and Kewaunee Counties to the south. A pier extends approximately 400 feet (ft) into the bay on the northern edge of the beach and forms a northern boundary for the beach study area. The beach extends approximately $1,000 \mathrm{ft}$ to the south of the pier to a boat launch and the northern edge of Horseshoe Point, which forms the southern boundary for the embayment that encompasses Murphy Park Beach. The beach at Murphy Park forms the eastern boundary of the study site (fig. 2).

The Murphy Park Beach watershed covers approximately 140 acres and includes park land, undeveloped woodland, part of a golf course, and several private residences. The watershed is underlain by dolomite bedrock of Silurian age that forms a steep ridge, known as the Niagara Escarpment, and a plateau in the eastern part of the watershed. Groundwater flow is generally from southeast to northwest along the western side of the Door Peninsula through fractures in the carbonate rocks (Sherrill, 1978). During the spring, groundwater seepage is visible along the beach; no seepage was observed during the study periods of August-September 2008 and July-August 2009 , although groundwater is expected to discharge below shallow beach water year-round. A concrete-lined pit toilet exists on the park premises, but no subterranean or surface wastewater discharges occur within Murphy Park. An ephemeral stream channel runs through the center of Murphy Park, south of the primary swimming area, but flow was not observed in this channel during the summer study periods and is therefore not shown in figures 1 or 2. A small perennial stream enters Horseshoe Bay between Horseshoe Point and the boat launch, approximately $800 \mathrm{ft}$ south of the beach area, and was considered to be outside of the study area that was defined as being bounded along the south edge by the boat launch sampling site. 


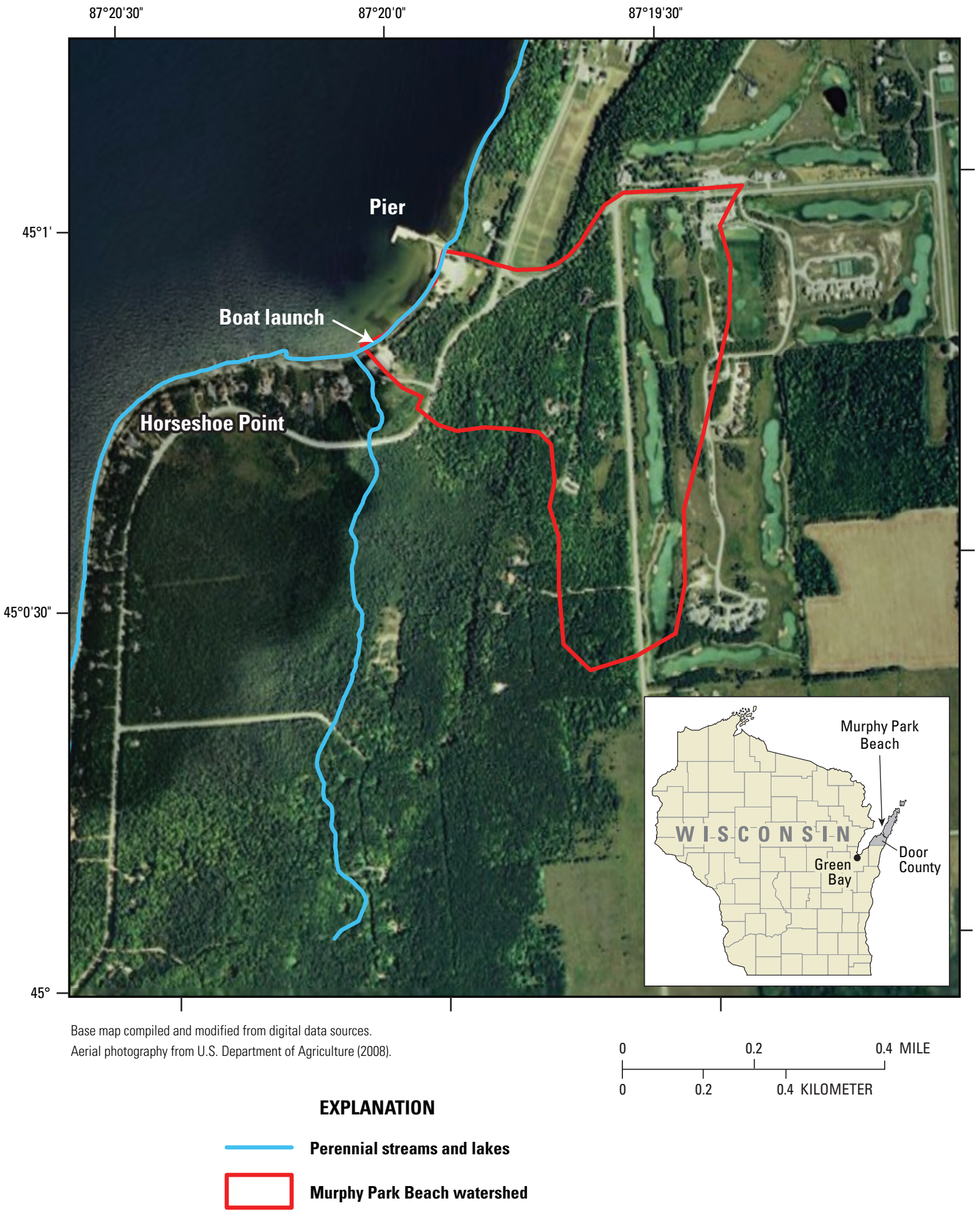

Figure 1. Location of Murphy Park Beach and watershed in Door County, Wisconsin. 


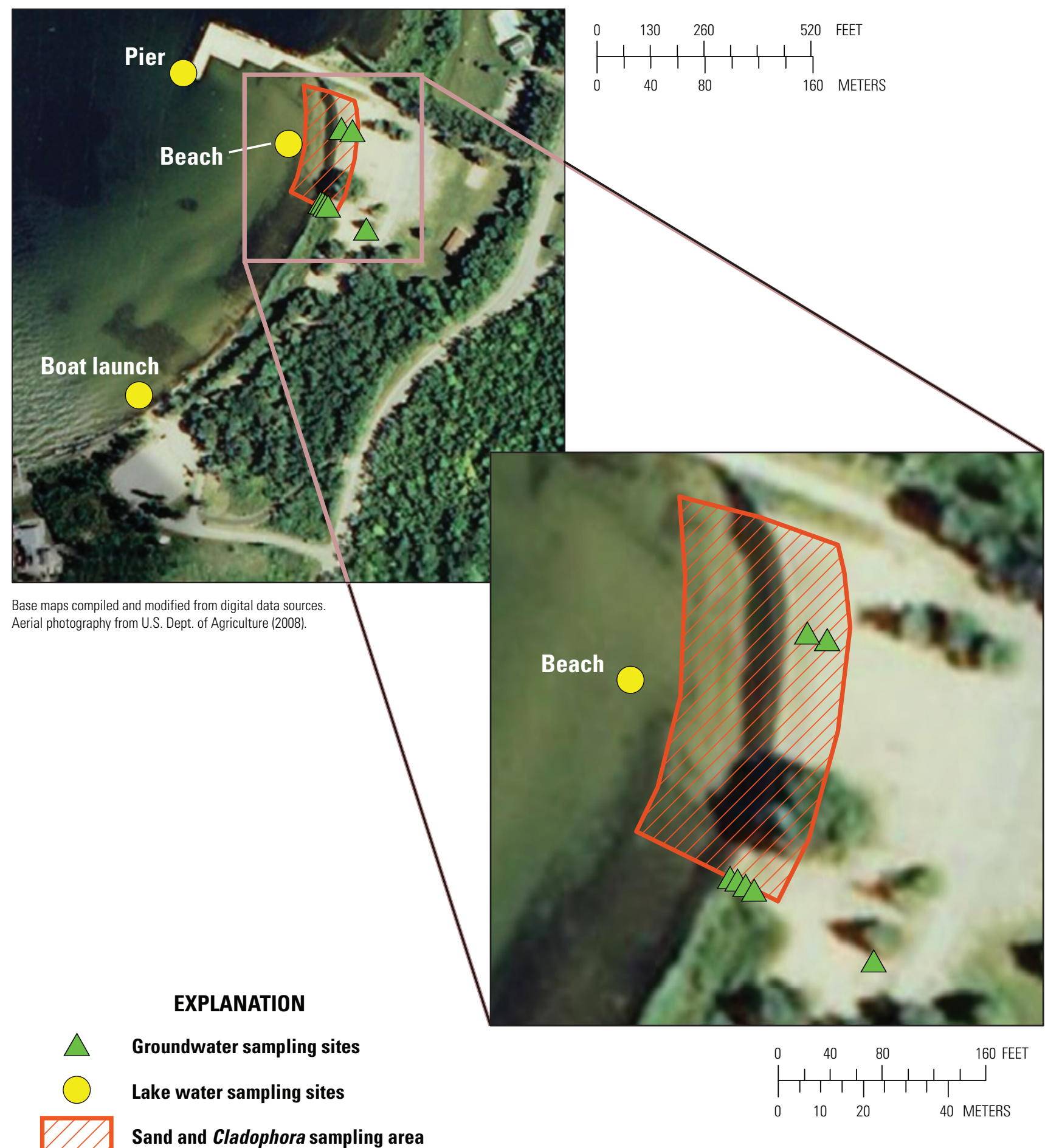

Figure 2. Locations of data-collection sites at Murphy Park Beach, 2008-9. 


\section{Study Methods and Sampling Sites}

U.S. Geological Survey (USGS) and University of Wisconsin-Oshkosh personnel collected samples for quantitative analysis of the fecal indicator bacteria E. coli and enterococci, analysis of the presence or absence of a suite of pathogenic bacteria, concentrations of suspended particulates in lake water, and analysis of a suite of basic water-chemistry characteristics at sites in Murphy Park. Basic water chemistry included cations, water temperature, $\mathrm{pH}$, specific conductance, turbidity, and acid neutralizing capacity. Sample collection and analysis for E. coli, enterococci, and pathogens followed the methods described by Zehms and others (2008), Englebert and others (2008), and Eaton and others (2005). E. coli and enterococci concentrations were expressed as most probable number per $100 \mathrm{ml}$ of water (MPN/100mL) or as most probable number per gram of dry sand (MPN/g). Pathogen presence was tested using PCR assays for signature genes of selected bacterial pathogens. Samples for analysis of basic water chemistry and suspended particulates were collected using the grab method, preserved, and then shipped to the Wisconsin State Laboratory of Hygiene. Preservation included acidification of cations with nitric acid to a $\mathrm{pH}$ less than 2 and chilling of all samples to approximately 4 degrees Celsius $\left({ }^{\circ} \mathrm{C}\right)$. All samples were unfiltered, except the filtered lake water samples as described below.

\section{Sampling Sites}

Sampling sites (fig. 2) were selected to evaluate sources and transport mechanisms of FIB and pathogens to beach water at Murphy Park Beach. The beach water site was considered the primary focus of the study, because FIB exceedances there trigger beach closure. Thus, the other sampling sites represented potential FIB and pathogen sources or transport pathways to the beach water. Sites evaluated for this study are shown in figure 2 and included the site and sample types listed below.

1. Lake water. The water of Green Bay could transport FIB and pathogens to the beach water via currents. Lake water sampling sites adjacent to the beach site included the pier and boat launch. Sampling at these sites captured FIB and pathogens potentially available for transport into the beach water column via currents. The beach water site is also included as a lake water sampling site in sections of the report describing sampling and laboratory methods and sample collection schedules.

2. Groundwater. Shallow groundwater is a potential source or transport mechanism, or both, of microbiological contaminants (Alexander and others, 2008) to the beach water column. Groundwater sampling sites included several shallow piezometers, or wells, at varying distances from the shoreline and a deep well about $150 \mathrm{ft}$ from the shoreline that provides drinking water. Piezometers were categorized as being near (typically less than $5 \mathrm{ft}$ from shore), middle (typically 5-15 ft from shore), or far from the shoreline (typically greater than $100 \mathrm{ft}$ from shore).

3. Suspended particulates. Filters were used to capture FIB and pathogens in lake water associated with suspended particulates larger than 63 microns (fine sand), between 63 and 1 micron (silt), and clay, colloids, or free-floating organisms smaller than 1 micron (filtrate). Samples for FIB associated with particulates were collected at the beach water and boat launch sites and are referred to as 63 micron, 1 micron, or filtrate.

4. Sand. Beach sand has been found to harbor high levels of FIB and represented a potential source of FIB and pathogens to beach water. Sand cores were collected representing upshore, swash-zone, and submerged sand.

5. Cladophora. Water within and adjacent to Cladophora mats was sampled to evaluate the potential for Cladophora mats to act as sources of FIB and pathogens to beach water at Murphy Park Beach. Samples were categorized as either interior or exterior of a Cladophora mat, and are referred to as either within or adjacent to a mat.

\section{Sampling Schedule}

Surface-water samples were collected into sterile 120-milliliter $(\mathrm{mL})$ plastic bottles 4 days per week at the beach site and 4 consecutive days every other week at the pier and boat launch sites. Groundwater samples, sand cores, and water samples associated with Cladophora were collected every other week and corresponded with the weeks when samples were collected at the pier and boat launch sites. Sampling for FIB associated with suspended particulates was targeted for periods of increased storm activity but always coincided with a sample from the beach. Sample collection was typically completed during the morning to minimize potential effects of FIB reduction due to solar radiation. Although this was not always possible, analyses of samples collected from the lake water sampling sites showed no statistically significant relation with time of day that a sample was collected. Table 1 summarizes which constituents were sampled at each site during 2008 and 2009. Sampling in 2008 focused on FIB in lake water at the beach and pier and in groundwater. Sampling in 2009 included collection of samples for analysis for pathogens, as well as samples of lake water at the boat launch sampling site, particulates, sand cores, and water sampling within and adjacent to Cladophora mats. 
Table 1. Dates, locations, and types of environmental samples collected at Murphy Park Beach, 2008-9.

[Dates are indicated by numerals for the month, day, and year. E, Escherichia coli; C, enterococci; W, water chemistry; A, ancillary data including: wave height, bather and avian counts (beach only), current direction and speed, turbidity, water temperature, specific conductance, and $\mathrm{pH} ; \mathrm{P}$, pathogen analysis; --, no data. Sand samples included collection of three cores of submerged, swash zone, and upshore sand at the beach]

\begin{tabular}{|c|c|c|c|c|c|c|c|c|}
\hline \multirow[t]{2}{*}{ Date } & \multicolumn{4}{|c|}{ Water-sample locations and types } & \multicolumn{2}{|c|}{$\begin{array}{l}\text { Filtered sediment and } \\
\text { water-sample locations } \\
\text { and types }\end{array}$} & \multirow[t]{2}{*}{ Sand } & \multirow[t]{2}{*}{$\begin{array}{l}\text { Cladophora } \\
\text { mats }\end{array}$} \\
\hline & Beach & Pier & Boat launch & Piezometers & Beach & Boat launch & & \\
\hline \multicolumn{9}{|c|}{2008} \\
\hline $8 / 11 / 2008$ & $\mathrm{E}, \mathrm{C}, \mathrm{W}$ & $\mathrm{E}, \mathrm{C}, \mathrm{W}$ & -- & $\mathrm{E}, \mathrm{C}, \mathrm{W}$ & -- & -- & -- & -- \\
\hline $8 / 12 / 2008$ & $\mathrm{E}, \mathrm{C}, \mathrm{W}$ & $\mathrm{E}, \mathrm{C}, \mathrm{W}$ & -- & -- & -- & -- & -- & -- \\
\hline $8 / 13 / 2008$ & $\mathrm{E}, \mathrm{C}, \mathrm{W}$ & $\mathrm{E}, \mathrm{C}, \mathrm{W}$ & -- & -- & -- & -- & -- & -- \\
\hline $8 / 14 / 2008$ & $\mathrm{E}, \mathrm{C}, \mathrm{W}$ & $\mathrm{E}, \mathrm{C}, \mathrm{W}$ & -- & -- & -- & -- & -- & -- \\
\hline $8 / 18 / 2008$ & $\mathrm{E}, \mathrm{C}, \mathrm{W}$ & $\mathrm{E}, \mathrm{C}, \mathrm{W}$ & -- & -- & -- & -- & -- & -- \\
\hline $8 / 19 / 2008$ & $\mathrm{E}, \mathrm{C}, \mathrm{W}$ & $\mathrm{E}, \mathrm{C}, \mathrm{W}$ & -- & -- & -- & -- & -- & -- \\
\hline $8 / 20 / 2008$ & $\mathrm{E}, \mathrm{C}, \mathrm{W}$ & $\mathrm{E}, \mathrm{C}, \mathrm{W}$ & -- & -- & -- & -- & -- & -- \\
\hline $8 / 21 / 2008$ & $\mathrm{E}, \mathrm{C}, \mathrm{W}$ & $\mathrm{E}, \mathrm{C}, \mathrm{W}$ & -- & -- & -- & -- & -- & -- \\
\hline $8 / 24 / 2008$ & $\mathrm{E}, \mathrm{C}, \mathrm{W}$ & $\mathrm{E}, \mathrm{C}, \mathrm{W}$ & -- & -- & -- & -- & -- & -- \\
\hline $8 / 25 / 2008$ & $\mathrm{E}, \mathrm{C}, \mathrm{W}$ & $\mathrm{E}, \mathrm{C}, \mathrm{W}$ & -- & -- & -- & -- & -- & -- \\
\hline $8 / 26 / 2008$ & $\mathrm{E}, \mathrm{C}, \mathrm{W}$ & $\mathrm{E}, \mathrm{C}, \mathrm{W}$ & -- & $\mathrm{E}, \mathrm{C}, \mathrm{W}$ & -- & -- & -- & -- \\
\hline $8 / 27 / 2008$ & E, C, W & $\mathrm{E}, \mathrm{C}, \mathrm{W}$ & -- & -- & -- & -- & -- & -- \\
\hline $9 / 3 / 2008$ & $\mathrm{E}, \mathrm{C}, \mathrm{W}$ & $\mathrm{E}, \mathrm{C}, \mathrm{W}$ & -- & $\mathrm{E}, \mathrm{C}, \mathrm{W}$ & -- & -- & -- & -- \\
\hline $9 / 4 / 2008$ & $\mathrm{E}, \mathrm{C}, \mathrm{W}$ & $\mathrm{E}, \mathrm{C}, \mathrm{W}$ & -- & -- & -- & -- & -- & -- \\
\hline $9 / 11 / 2008$ & $\mathrm{E}, \mathrm{C}, \mathrm{W}$ & $\mathrm{E}, \mathrm{C}, \mathrm{W}$ & -- & $\mathrm{E}, \mathrm{C}, \mathrm{W}$ & -- & -- & -- & -- \\
\hline \multicolumn{9}{|c|}{2009} \\
\hline 7/9/2009 & $\mathrm{E}, \mathrm{C}, \mathrm{W}, \mathrm{A}$ & $\mathrm{E}, \mathrm{C}, \mathrm{W}, \mathrm{A}$ & $\mathrm{E}, \mathrm{C}, \mathrm{W}, \mathrm{A}$ & E, C, W & -- & -- & -- & -- \\
\hline 7/10/2009 & -- & -- & -- & -- & -- & -- & E, C & $\mathrm{E}, \mathrm{C}$ \\
\hline 7/13/2009 & E, C, A & -- & -- & -- & -- & -- & -- & -- \\
\hline $7 / 14 / 2009$ & $\mathrm{E}, \mathrm{C}, \mathrm{A}$ & -- & -- & -- & -- & -- & -- & -- \\
\hline $7 / 15 / 2009$ & E, C, A & -- & -- & -- & -- & -- & -- & -- \\
\hline $7 / 16 / 2009$ & $\mathrm{E}, \mathrm{C}, \mathrm{A}$ & -- & -- & -- & -- & -- & -- & -- \\
\hline $7 / 20 / 2009$ & E, C, A & E, C, A & $\mathrm{E}, \mathrm{C}, \mathrm{A}$ & E, C & -- & -- & -- & -- \\
\hline $7 / 21 / 2009$ & $\mathrm{E}, \mathrm{C}, \mathrm{A}$ & E, C, A & $\mathrm{E}, \mathrm{C}, \mathrm{A}$ & E, C & -- & -- & E, C & E, C \\
\hline $7 / 22 / 2009$ & $\mathrm{E}, \mathrm{C}, \mathrm{W}, \mathrm{A}$ & $\mathrm{E}, \mathrm{C}, \mathrm{W}, \mathrm{A}$ & $\mathrm{E}, \mathrm{C}, \mathrm{W}, \mathrm{A}$ & E, C, W & -- & -- & E, C & E, C \\
\hline $7 / 23 / 2009$ & $\mathrm{E}, \mathrm{C}, \mathrm{A}$ & $\mathrm{E}, \mathrm{C}, \mathrm{A}$ & $\mathrm{E}, \mathrm{C}, \mathrm{A}$ & $\mathrm{E}, \mathrm{C}$ & -- & -- & -- & -- \\
\hline $7 / 27 / 2009$ & $\mathrm{E}, \mathrm{C}, \mathrm{A}$ & -- & -- & -- & E, C & -- & -- & -- \\
\hline $7 / 28 / 2009$ & $\mathrm{E}, \mathrm{C}, \mathrm{A}$ & -- & -- & -- & E, C & $\mathrm{E}, \mathrm{C}$ & -- & -- \\
\hline $7 / 29 / 2009$ & E, C, A & -- & -- & -- & -- & -- & -- & -- \\
\hline $7 / 30 / 2009$ & E, C, A & -- & -- & -- & -- & -- & -- & -- \\
\hline $8 / 1 / 2009$ & $\mathrm{E}, \mathrm{C}, \mathrm{W}, \mathrm{A}$ & $\mathrm{E}, \mathrm{C}, \mathrm{W}, \mathrm{A}$ & $\mathrm{E}, \mathrm{C}, \mathrm{W}, \mathrm{A}$ & $\mathrm{E}, \mathrm{C}, \mathrm{W}$ & -- & -- & E, C & $\mathrm{E}, \mathrm{C}$ \\
\hline $8 / 3 / 2009$ & $\mathrm{E}, \mathrm{C}, \mathrm{A}$ & $\mathrm{E}, \mathrm{C}, \mathrm{A}$ & $\mathrm{E}, \mathrm{C}, \mathrm{A}$ & $\mathrm{E}$ & -- & -- & -- & -- \\
\hline $8 / 5 / 2009$ & $\mathrm{E}, \mathrm{C}, \mathrm{A}, \mathrm{P}$ & $\mathrm{E}, \mathrm{C}, \mathrm{A}, \mathrm{P}$ & $\mathrm{E}, \mathrm{C}, \mathrm{A}, \mathrm{P}$ & E, C, P & -- & -- & $\mathrm{E}, \mathrm{C}$ & E, C \\
\hline 8/6/2009 & $\mathrm{E}, \mathrm{C}, \mathrm{A}, \mathrm{P}$ & $\mathrm{E}, \mathrm{C}, \mathrm{A}, \mathrm{P}$ & $\mathrm{E}, \mathrm{C}, \mathrm{A}, \mathrm{P}$ & E, C, P & -- & -- & -- & -- \\
\hline 8/10/2009 & E, C, A & -- & -- & -- & -- & -- & -- & -- \\
\hline 8/11/2009 & $\mathrm{E}, \mathrm{C}, \mathrm{A}$ & -- & -- & -- & -- & -- & -- & -- \\
\hline $8 / 12 / 2009$ & E, C, A & -- & -- & -- & -- & -- & -- & -- \\
\hline $8 / 13 / 2009$ & $\mathrm{E}, \mathrm{C}, \mathrm{A}$ & -- & -- & -- & -- & -- & -- & -- \\
\hline
\end{tabular}


Table 1. Dates, locations, and types of environmental samples collected at Murphy Park Beach, 2008-9.-Continued

[Dates are indicated by numerals for the month, day, and year. E, Escherichia coli; C, enterococci; W, water chemistry; A, ancillary data including: wave height, bather and avian counts (beach only), current direction and speed, turbidity, water temperature, specific conductance, and $\mathrm{pH}$; $\mathrm{P}$, pathogen analysis; --, no data. Sand samples included collection of three cores of submerged, swash zone, and upshore sand at the beach]

\begin{tabular}{|c|c|c|c|c|c|c|c|c|}
\hline \multicolumn{9}{|c|}{ 2009-continued } \\
\hline $8 / 17 / 2009$ & $\mathrm{E}, \mathrm{C}, \mathrm{A}, \mathrm{P}$ & $\mathrm{E}, \mathrm{C}, \mathrm{A}, \mathrm{P}$ & $\mathrm{E}, \mathrm{C}, \mathrm{A}, \mathrm{P}$ & $\mathrm{E}, \mathrm{C}, \mathrm{P}$ & -- & -- & -- & -- \\
\hline $8 / 18 / 2009$ & $\mathrm{E}, \mathrm{C}, \mathrm{W}, \mathrm{A}, \mathrm{P}$ & $\mathrm{E}, \mathrm{C}, \mathrm{W}, \mathrm{A}, \mathrm{P}$ & $\mathrm{E}, \mathrm{C}, \mathrm{W}, \mathrm{A}, \mathrm{P}$ & $\mathrm{E}, \mathrm{C}, \mathrm{W}, \mathrm{P}$ & -- & -- & $\mathrm{E}, \mathrm{C}$ & $\mathrm{E}, \mathrm{C}$ \\
\hline $8 / 19 / 2009$ & $\mathrm{E}, \mathrm{C}, \mathrm{A}, \mathrm{P}$ & $\mathrm{E}, \mathrm{C}, \mathrm{A}, \mathrm{P}$ & $\mathrm{E}, \mathrm{C}, \mathrm{A}, \mathrm{P}$ & $\mathrm{E}, \mathrm{C}, \mathrm{P}$ & -- & -- & -- & -- \\
\hline $8 / 20 / 2009$ & $\mathrm{E}, \mathrm{C}, \mathrm{A}, \mathrm{P}$ & $\mathrm{E}, \mathrm{C}, \mathrm{A}, \mathrm{P}$ & $\mathrm{E}, \mathrm{C}, \mathrm{A}, \mathrm{P}$ & E, C, P & E, C & E, C & E, C & $\mathrm{E}, \mathrm{C}$ \\
\hline $8 / 24 / 2009$ & $\mathrm{E}, \mathrm{C}, \mathrm{A}, \mathrm{P}$ & $\mathrm{E}, \mathrm{C}, \mathrm{A}, \mathrm{P}$ & $\mathrm{E}, \mathrm{C}, \mathrm{A}, \mathrm{P}$ & -- & -- & -- & -- & -- \\
\hline $8 / 25 / 2009$ & E, C, A, P & E, C, A, P & E, C, A, P & -- & $\mathrm{E}, \mathrm{C}$ & $\mathrm{E}, \mathrm{C}$ & -- & -- \\
\hline $8 / 26 / 2009$ & $\mathrm{E}, \mathrm{C}, \mathrm{A}, \mathrm{P}$ & $\mathrm{E}, \mathrm{C}, \mathrm{A}, \mathrm{P}$ & $\mathrm{E}, \mathrm{C}, \mathrm{A}, \mathrm{P}$ & -- & -- & -- & -- & -- \\
\hline
\end{tabular}

\section{Lake Water Sampling}

Samples from the lake water sampling sites were collected using a grab-sampling technique at about $1.0 \mathrm{ft}$ below the surface in water with a depth of about $2 \mathrm{ft}$, except at the pier, where the water depth was approximately $6 \mathrm{ft}$. Samples were collected at the end of the pier and at the boat launch in 2009 in an effort to evaluate potential transport of FIB into the beach area. A stream enters Horseshoe Bay between Horseshoe Point and the boat launch. Because the boat launch is between Murphy Park Beach and the stream, the samples collected at the boat launch were expected to integrate water from the stream and from long-shore currents flowing northeast along the eastern shoreline between Horseshoe Point and the beach. Thus, the intention was to characterize potential transport of FIB into the beach area from external sources by collecting samples at the pier and boat launch sites.

\section{Groundwater Sampling}

Groundwater samples were collected by first evacuating approximately 3 liters (L) (approximately four well volumes) of well water at a moderate pumping rate by use of a peristaltic pump and high-density polyethylene tubing, followed by sample collection with the same system. Groundwater samples from a public drinking water well were collected by first evacuating approximately $5 \mathrm{~L}$ of water (less than one well volume) at a moderate rate by use of a hand pump prior to sample collection directly from the well spigot.

\section{Suspended Particulates in Lake Water}

Samples for FIB associated with suspended particulates were collected through direct sampling in the field. Specifically, lake water was pumped through a series of nylon filters with pore openings of 63 microns and 1 micron for approximately $1 \mathrm{hr}$ until either the 63-micron or 1-micron filter appeared caked with material. The suspended particulates collected on the filters and the filters themselves were placed in sterile jars and transported to the lab, where the filters and particulates were rinsed with deionized water. FIB concentrations from this rinse water were reported as MPN $/ \mathrm{mL}$ of rinse water, which were then normalized by the total amount of water pumped through the filters and finally converted to MPN/100mL of pumped water. Filtrate water was also collected and analyzed for FIB.

\section{Sand Sampling}

E. coli and enterococci from sand cores were collected using the methods of Zehms and others (2008), which included collecting three sand cores in each of three beach sand environments: upshore, swash zone, and submerged. Submerged sand cores were collected at approximately $2-\mathrm{ft}$ water depth, swash-zone sand was collected where wave action maintained high moisture in the beach sand, and upshore sand was collected beyond the area of wave action, $10-20 \mathrm{ft}$ away from the shoreline. In the lab, the sand was washed with deionized water, and this filtrate was analyzed for $E$. coli and enterococci by the defined substrate methods Colilert ${ }^{\circledR}$ and Enterolert ${ }^{\circledR}$, and the results were expressed in units of MPN/100mL. Finally, the sand was dried and each MPN/100mL result was converted to MPN/g of dry sand.

\section{Cladophora Sampling}

Water samples in and adjacent to Cladophora mats were collected using the methods of Englebert and others (2008), with multiple water samples collected within Cladophora mats and at multiple distances away from the Cladophora mat. Visual estimates of relative Cladophora abundance were also made during each sampling event. 


\section{Ancillary Data}

Ancillary data were collected at the time of sample collection at each of the three lake water sampling sites and included: wave height, water temperature, current direction and speed, bather and bird counts, turbidity, specific conductance, and $\mathrm{pH}$. Ancillary data were collected using the same protocols as Zehms and others (2008). Continuous data were also recorded at the base of a buoy located in approximately $6 \mathrm{ft}$ of water and approximately $50 \mathrm{ft}$ south of the pier, and additional continuous data were recorded at an onshore companion site during the summer of 2009. Continuous data included water level, turbidity, specific conductance, precipitation, and solar radiation.

\section{Pathogens}

Pathogen samples were collected for lake water and groundwater sampling sites starting on Aug. 5, 2009 (table 1). Samples were processed by the USGS Michigan Water Science Center Microbiology Laboratory within $48 \mathrm{hr}$ from the time of sampling. Immediately upon arrival at the lab, samples were unpacked and an identification number was assigned to each sample for tracking the sample.

The targeted bacterial pathogens were human-pathogenic enterococci, Shigella sonnei, Shiga toxin-producing E. coli (STEC), Salmonella species, and Campylobacter jejuni and coli. Growth media and enrichment parameters for each target organism are shown in table 2. Solid (agar) media for the enrichment for E. coli/Shigella ( $\mathrm{mFC}$ medium) and enterococci (mEI medium) were prepared according the manufacturer's instructions. Membrane filtration was done according to standard procedures (Eaton and others, 2005; U.S. Environmental Protection Agency, 2000). Selective enrichments for Campylobacter and Salmonella were done by inoculating the appropriate broth (table 2) with a filter containing the filtrate from $100 \mathrm{~mL}$ of sample water. Observations were enumerated from the agar plates, if appropriate, and broth enrichments.
Membrane filters with subsequent growth were frozen directly at $-20^{\circ} \mathrm{C}$ until further analysis. For broth cultures, following agitation for 15 minutes, membrane filters were aseptically removed and the broth centrifuged to form a pellet. Supernatant was decanted and the pellet was resuspended in $1 \mathrm{~mL}$ of 20 percent glycerol prepared in one-half strength Phosphate Buffered Solution. Glycerol preparations were stored at $-70^{\circ} \mathrm{C}$ until deoxyribonucleic acid (DNA) extraction, which took place up to 2 years later. For DNA extraction, filters cut into eighths, or pellets from broth cultures, were thawed at room temperature, and DNA was then extracted from all samples using the alkaline polyethylene glycol method of Chomczynski and Rymaszewski (2006). Extracted DNA was stored at $-20^{\circ} \mathrm{C}$, and was analyzed within 1 week of extraction. All equipment used in filtering was cleaned and sterilized daily and checked prior to each use. A laboratory blank was run daily by filtering Phosphate Buffered Solution through a filter cup onto a filter for each medium prior to testing, and a laboratory replicate was run weekly.

STEC E. coli and pathogenic enterococci were detected using previously published methods (Duris and others, 2009; Haack and others, 2009). Shigella sonnei was detected using modifications of the procedure of Islam and others (1993). Campylobacter jejuni and C. coli were detected using modifications of the methods of Inglis and Kalischuk (2003). Salmonella and pathogenic Salmonella species were detected using modifications of the methods of Chiu and Ou (1996). Standard quality assurance and control procedures were followed for all PCR reactions (U.S. Environmental Protection Agency, 2004). Detection limits for all PCR reactions were determined using serial dilution of DNA from control organisms (table 3). For approximately every 20 samples of any given PCR reaction, PCR-positive controls and PCR-negative controls (no template reactions) were included. Environmental matrix issues were minimized in these methods by analyzing DNA extracted from pre-enriched cultures. All PCR assays were performed using 1 microliter (1-100 nanograms) of template DNA. Prior studies indicate a range of detection limits of 20-200 cells for the various reactions (Haack and others, 2009).

Table 2. Growth medium and enrichment parameters for target pathogenic bacteria.

$\left[\mathrm{mL}\right.$, milliliters; \pm , plus or minus; ${ }^{\circ} \mathrm{C}$, degrees Celsius $]$

\begin{tabular}{lllcll}
\hline Target organism & Growth medium & Purpose & $\begin{array}{c}\text { Volume } \\
\text { filtered, } \\
\text { in } \mathbf{~ m L}\end{array}$ & Incubation temperature & Reference \\
\hline Enterococci & $\mathrm{mEI}$ & Enrichment & 100 & $41.5^{\circ} \mathrm{C} \pm 1.0^{\circ} \mathrm{C}$ for $22-24$ hours & $\begin{array}{c}\text { U.S. Environmental Protection } \\
\text { Agency }(2006)\end{array}$ \\
Shigella & $\mathrm{mFC}$ & Enrichment & 100 & $44^{\circ} \mathrm{C} \pm 1.0^{\circ} \mathrm{C}$ for $22-24$ hours & Eaton and others (2005) \\
Escherichia coli & $\mathrm{mFC}$ & Enrichment & 100 & $44^{\circ} \mathrm{C} \pm 1.0^{\circ} \mathrm{C}$ for $22-24$ hours & Eaton and others $(2005)$ \\
Salmonella & Rappaport-Vassiliadis & Enrichment & 100 & $37^{\circ} \mathrm{C} \pm 1.0^{\circ} \mathrm{C}$ for $22-24$ hours & Vassiliadis and others $(1978)$ \\
Campylobacter & Bolton broth & Enrichment & 100 & $\begin{array}{l}37^{\circ} \mathrm{C} \pm 1.0^{\circ} \mathrm{C} \text { for } 4 \text { hours } \\
41.5^{\circ} \mathrm{C} \pm 1.0^{\circ} \mathrm{C} \text { for } 48 \text { hours }\end{array}$ & Baylis and others $(200)$ \\
\hline
\end{tabular}


Table 3. Positive controls and detection limits for polymerase chain reaction (PCR) assays.

[ng/ $\mu \mathrm{L}$, nanograms per microliter; E. coli, Escherichia coli]

\begin{tabular}{|c|c|c|c|c|}
\hline Target organism & Gene targets & Band size & Positive control & $\begin{array}{l}\text { Detection limit, } \\
\text { in } \mathrm{ng} / \mathrm{\mu L}\end{array}$ \\
\hline Enterococci & esp & 954 & Enterococcus faecium E53 & 0.0001 \\
\hline Shigella sonnei & $i p a H$ & 620 & ATCC 9290 & .0008 \\
\hline Escherichia coli & $\begin{array}{l}\text { eaeA } \\
\text { stxl } \\
\text { stx2 } \\
\text { E. coli } 16 \mathrm{~S} \text { rDNA } \\
r f b_{0157}\end{array}$ & $\begin{array}{l}890 \\
779 \\
614 \\
544 \\
420\end{array}$ & $\begin{array}{l}\text { ATC } 35150 \\
\text { ATC } 35150 \\
\text { ATC } 35150 \\
\text { ATC } 35150 \\
\text { ATC } 35150\end{array}$ & $\begin{array}{l}.01 \\
.01 \\
.01 \\
.01 \\
.0001\end{array}$ \\
\hline Salmonella & $\begin{array}{l}\operatorname{spv} C \\
\operatorname{inv} A\end{array}$ & $\begin{array}{l}571 \\
244\end{array}$ & $\begin{array}{l}\text { Salmonella typhimurium ATCC } 14028 \\
\text { Salmonella typhimurium ATCC } 14028\end{array}$ & $\begin{array}{l}.0025 \\
.0025\end{array}$ \\
\hline Campylobacter jejuni and coli & 16S rDNA & 857 & Campylobacter jejuni ATCC 29428 & .001 \\
\hline
\end{tabular}

\section{Multivariate Statistical Analysis}

E. coli concentrations from samples collected in 2009 and 202 possible explanatory variables measured in 2009 were used in a multivariate analysis to explore potential statistical relations and evaluate which variables explain the most variability in E. coli concentrations for this period of study (table 4). These variables included data collected directly for this study, data gathered from nearby National Weather Service stations, and modeling results from the Great Lakes
Forecasting System (Schwab and Bedford, 1999). Daily data collected at the beach and daily variables collected by the National Weather Service were used directly. For all other variables, data or modeling results were available on a finer time scale of less than 1 day $(1,2,3,6$, and $12 \mathrm{hr})$. For these subdaily variables, the value from the nearest previous measurement as well as a number of chosen temporal summations, mean, maximum, and median values were used in multivariate analysis (table 4).

Table 4. Variables used in multivariate regression for Escherichia coli (E. coli) concentrations at Murphy Park Beach, July-September 2009.

[UW, University of Wisconsin; USGS, U.S. Geological Survey; min, minute; hr, hour; NWS, National Weather Service; Wis., Wisconsin; NOAA, National Oceanic and Atmospheric Administration]

\begin{tabular}{|c|c|c|c|c|}
\hline Data type & Location & Source & $\begin{array}{l}\text { Time frequency } \\
\text { of raw data }\end{array}$ & Variables used in analysis \\
\hline $\begin{array}{l}\text { Manual data collection } \\
\text { at beach }\end{array}$ & Murphy Park Beach & UW-Oshkosh/USGS & 1 per day & Raw data. \\
\hline \multirow[t]{3}{*}{$\begin{array}{l}\text { Continuous monitoring } \\
\text { at beach }\end{array}$} & Murphy Park Beach & USGS & $5 \mathrm{~min}$ & $\begin{array}{l}\text { Rainfall: summation of } 0.5-, 1-, 2-, 3-\text {, } \\
\text { 5-, and 10-day rainfall. }\end{array}$ \\
\hline & & & & $\begin{array}{l}\text { Solar radiation: nearest previous } \\
\text { measurement and mean, maximum, } \\
\text { and median of past } 12,24,48,96,144, \\
\text { and } 192 \mathrm{hrs} \text {. }\end{array}$ \\
\hline & & & & $\begin{array}{l}\text { Turbidity, specific conductance, water } \\
\text { temperature: nearest previous } \\
\text { measurement and mean and maximum } \\
\text { of past } 1,2,3,6,12 \text {, and } 24 \text { hrs. }\end{array}$ \\
\hline $\begin{array}{l}\text { Continuous radar } \\
\text { rainfall }\end{array}$ & Modeled results & NWS & $1 \mathrm{hr}$ & $\begin{array}{l}\text { Rainfall: summation of } 0.5,1,2,3,4,5 \text {, } \\
\text { and every } 2 \text { days from } 6-40 \text { days. }\end{array}$ \\
\hline $\begin{array}{l}\text { Great Lakes } \\
\quad \text { Forecasting System }\end{array}$ & Modeled results & NOAA & $1 \mathrm{hr}$ & $\begin{array}{l}\text { Lake-surface elevation, surface and } \\
\text { depth-integrated water velocity } \\
\text { (perpendicular and parallel to beach), } \\
\text { wave height, wave direction: mean and } \\
\text { maximum of past } 1-24 \text { hrs. }\end{array}$ \\
\hline
\end{tabular}


Four levels of statistical analysis were used to explore this data. All analyses were conducted using R statistical software (R Development Core Team, 2011). The four levels of analyses were performed as follows.

1. Subdaily time series variable selection. For each variable that was available on a subdaily basis, all temporal summation variables derived from that physical variable and, as appropriate, the log transformations were used to generate Pearson correlation coefficients with $E$. coli concentration. The temporal summation variable with the highest Pearson correlation coefficient for each physical variable was chosen for subsequent analyses.

2. Recursive partitioning analysis. All daily measurements as well as the subdaily variables that were chosen in level 1 were used in a recursive partitioning analysis also referred to as classification and regression tree, to explore relations between E. coli concentrations and predictor variables. Recursive partitioning analysis provides an option for exploring complex data relations with nonlinear structure and variable interactions by successively splitting the data into increasingly homogeneous subsets. Stopping rules are used to reach final splitting points or "terminal nodes." The recursive partitioning process results in a flow chart or "tree" that splits data based on a set of rules. Recursive partitioning analyses are particularly well suited for use with complex ecological data (De'Ath and Fabricius. 2000). This analysis was conducted independently two times, once for those variables that were available on a daily time interval and a second time for derivatives of the subdaily time series variables that were computed to match the daily sample times (table 4). The variables that proved to be somewhat influential were carried forward for subsequent level 3 and 4 analyses. These variables included the first three split variables as well as close competitor variables, which would provide a valuable split if the chosen split variable were not present, and close surrogate variables, which would provide a split similar to the chosen split variable.

3. Multiple ordinary least squared linear regression used all possible four variable combinations from those variables surviving level 1 and 2 analyses, which is referred to as "all subsets regression."
4. Stepwise regression used the resulting variables from level 3 analysis along with the three most influential variables in both of the level 2 recursive partitioning analyses. It was necessary to reduce the variables from the original 202 for stepwise regression analysis due to the limitations of ordinary least squared regression and to avoid overfitting of the final regression model.

The first three levels were used to aid with variable selection for the fourth level. Results from the second and fourth levels were used to draw final conclusions on potential influential variables identified from this multivariate analysis.

\section{FIB Concentrations at Potential Source Reservoirs}

\section{FIB in Lake Water}

FIB concentrations in water samples collected at the boat launch for only 2009 and the pier for 2008 and 2009 combined were compared with results from beach water to evaluate potential sources for transport of FIB to the beach area (fig. 3, table 5). Daily FIB concentrations at the boat launch and the pier were directly compared to FIB concentrations in beach water by normalizing concentrations at the boat launch and the pier with concentrations in beach water (fig. $3 C$ and $D$ ). This type of direct comparison by normalizing with FIB concentrations in beach water from the same day was performed for all potential aquatic source locations, including groundwater, suspended particulates, and Cladophora-associated water. E. coli concentrations in water at the beach were generally higher than those in water at either the boat launch or the pier, except on a few dates when $E$. coli concentrations at the boat launch (July 23 and Aug. 26, 2009) and E. coli at the pier (Aug. 3, 24, and 26, 2009) exceeded those measured at the beach (fig. 4A, table 5). Concentrations of enterococci in beach water were higher than those at the pier and boat launch sites, except on a few occasions at the boat launch (July 23 and Aug. 5, 2009) and at the pier (Aug. 24 and Sept. 11, 2008, and Aug. 19 and Sept. 17, 2009). Aside from the E. coli measured at the boat launch on July 23, 2009, the E. coli concentrations at the boat launch and the pier were always less than the U.S. Environmental Protection Agency water-quality criterion of $235 \mathrm{MPN} / 100 \mathrm{~mL}$. 

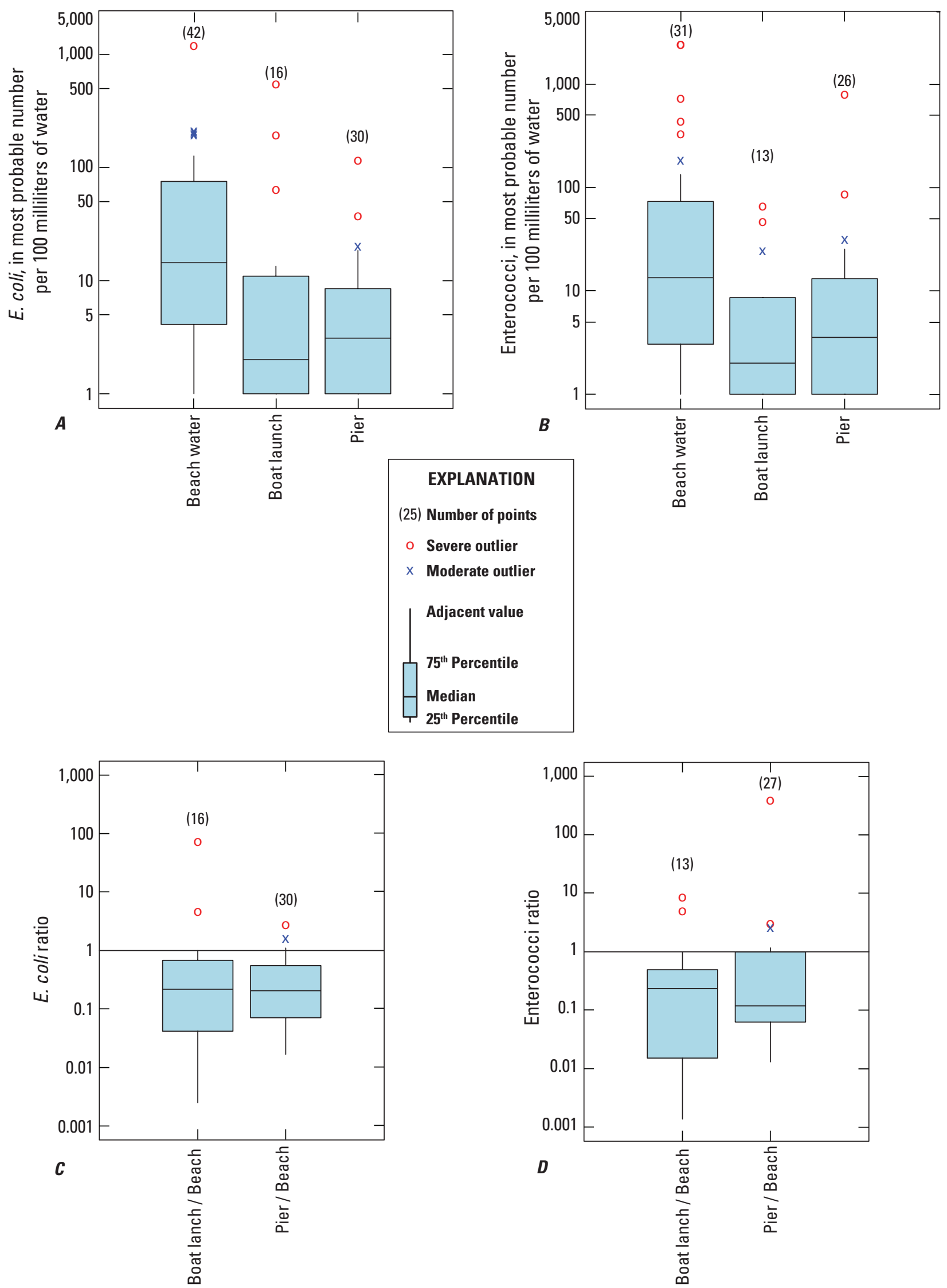

Figure 3. Boxplots of $A$, Escherichia coli (E. coli) and $B$, enterococci concentrations in lake water and ratios of $C$, E. coli and $D$, enterococci for lake water sites at Murphy Park Beach, 2008-9. 
Table 5. Fecal indicator bacteria concentrations in samples from the lake water sampling sites and current directions at the three lake water sampling sites at Murphy Park Beach, 2008-9.

[Dates are indicated by numerals for the month, day, and year. E. coli, Escherichia coli; MPN/100mL, most probable number per 100 milliliters; --, no data]

\begin{tabular}{|c|c|c|c|c|c|c|c|c|c|}
\hline \multirow[b]{2}{*}{ Date } & \multicolumn{3}{|c|}{ Beach } & \multicolumn{3}{|c|}{ Boat launch } & \multicolumn{3}{|c|}{ Pier } \\
\hline & $\begin{array}{c}\text { E. coli } \\
\text { (MPN/100mL) }\end{array}$ & $\begin{array}{l}\text { Enterococci } \\
\text { (MPN/100mL) }\end{array}$ & $\begin{array}{c}\text { Current } \\
\text { direction } \\
\text { (degrees } \\
\text { from north) }\end{array}$ & $\begin{array}{c}\text { E. coli } \\
\text { (MPN/100mL) }\end{array}$ & $\begin{array}{l}\text { Enterococci } \\
\text { (MPN/100mL) }\end{array}$ & $\begin{array}{c}\text { Current } \\
\text { direction } \\
\text { (degrees } \\
\text { from north) }\end{array}$ & $\begin{array}{c}\text { E. coli } \\
\text { (MPN/100mL) }\end{array}$ & $\begin{array}{l}\text { Enterococci } \\
\text { (MPN/100mL) }\end{array}$ & $\begin{array}{c}\text { Current } \\
\text { direction } \\
\text { (degrees } \\
\text { from north) }\end{array}$ \\
\hline $8 / 11 / 2008$ & 206 & 328 & -- & -- & -- & -- & 6 & 6 & -- \\
\hline $8 / 12 / 2008$ & 28 & 10 & -- & -- & -- & -- & 2 & 1 & -- \\
\hline $8 / 13 / 2008$ & 75 & 20 & -- & -- & -- & -- & 4 & 1 & -- \\
\hline $8 / 14 / 2008$ & 91 & 40 & -- & -- & -- & -- & 5 & 2 & -- \\
\hline $8 / 18 / 2008$ & 39 & 13 & -- & -- & -- & -- & 3 & 5 & -- \\
\hline $8 / 19 / 2008$ & 127 & 184 & -- & -- & -- & -- & 16 & 13 & -- \\
\hline $8 / 20 / 2008$ & 4 & 3 & -- & -- & -- & -- & 1 & 2 & -- \\
\hline $8 / 21 / 2008$ & 3 & 6 & -- & -- & -- & -- & 1 & 2 & -- \\
\hline $8 / 24 / 2008$ & 13 & 2 & -- & -- & -- & -- & 15 & 792 & -- \\
\hline $8 / 26 / 2008$ & 6 & 37 & -- & -- & -- & -- & 1 & 2 & -- \\
\hline $9 / 3 / 2008$ & 1 & 1 & -- & -- & -- & -- & 1 & 1 & -- \\
\hline $9 / 4 / 2008$ & 1 & 2 & -- & -- & -- & -- & 1 & 2 & -- \\
\hline $9 / 11 / 2008$ & 11 & 14 & -- & -- & -- & -- & 3 & 16 & -- \\
\hline 7/9/2009 & 5 & 81 & 360 & 1 & 24 & 360 & 1 & 10 & 90 \\
\hline 7/13/2009 & 6 & 3 & 95 & -- & -- & -- & -- & -- & -- \\
\hline $7 / 14 / 2009$ & 1 & 1 & 95 & -- & -- & -- & -- & -- & -- \\
\hline $7 / 15 / 2009$ & 60 & 2,420 & 90 & -- & -- & -- & -- & -- & -- \\
\hline $7 / 16 / 2009$ & 12 & 46 & 90 & -- & -- & -- & -- & -- & -- \\
\hline $7 / 20 / 2009$ & 17 & 9 & 360 & 1 & 2 & 345 & 1 & 1 & 10 \\
\hline $7 / 21 / 2009$ & 1 & 1 & 270 & 1 & 1 & 270 & 1 & 1 & 360 \\
\hline $7 / 22 / 2009$ & 56 & 66 & 245 & 1 & 1 & 190 & 19 & 1 & 360 \\
\hline $7 / 23 / 2009$ & 7 & 9 & 90 & 548 & 47 & 190 & 1 & 1 & 190 \\
\hline $7 / 28 / 2009$ & 2 & -- & 90 & -- & -- & -- & -- & -- & -- \\
\hline $7 / 29 / 2009$ & 2 & -- & 90 & -- & -- & -- & -- & -- & -- \\
\hline 7/30/2009 & 84 & -- & 90 & -- & -- & -- & -- & -- & -- \\
\hline
\end{tabular}


Table 5. Fecal indicator bacteria concentrations in samples from the lake water sampling sites and current directions at the three lake water sampling sites at Murphy Park Beach, 2008-9.-Continued

[Dates are indicated by numerals for the month, day, and year. E. coli, Escherichia coli; MPN/100mL, most probable number per 100 milliliters; --, no data]

\begin{tabular}{|c|c|c|c|c|c|c|c|c|c|}
\hline \multirow[b]{2}{*}{ Date } & \multicolumn{3}{|c|}{ Beach } & \multicolumn{3}{|c|}{ Boat launch } & \multicolumn{3}{|c|}{ Pier } \\
\hline & $\begin{array}{c}\text { E. coli } \\
\text { (MPN/100mL) }\end{array}$ & $\begin{array}{l}\text { Enterococci } \\
\text { (MPN/100mL) }\end{array}$ & $\begin{array}{c}\text { Current } \\
\text { direction } \\
\text { (degrees } \\
\text { from north) }\end{array}$ & $\begin{array}{c}\text { E. coli } \\
(\mathrm{MPN} / 100 \mathrm{~mL})\end{array}$ & $\begin{array}{l}\text { Enterococci } \\
\text { (MPN/100mL) }\end{array}$ & $\begin{array}{c}\text { Current } \\
\text { direction } \\
\text { (degrees } \\
\text { from north) }\end{array}$ & $\begin{array}{c}\text { E. coli } \\
\text { (MPN/100mL) }\end{array}$ & $\begin{array}{l}\text { Enterococci } \\
\text { (MPN/100mL) }\end{array}$ & $\begin{array}{c}\text { Current } \\
\text { direction } \\
\text { (degrees } \\
\text { from north) }\end{array}$ \\
\hline $8 / 1 / 2009$ & 195 & 435 & 45 & 5 & 3 & 45 & 37 & 13 & 45 \\
\hline $8 / 3 / 2009$ & 8 & 22 & 45 & 2 & 1 & 45 & 12 & 5 & 45 \\
\hline $8 / 5 / 2009$ & 4 & 1 & 90 & 2 & 9 & 90 & 1 & 1 & 15 \\
\hline $8 / 6 / 2009$ & 210 & 727 & 45 & 9 & 1 & 45 & 4 & 86 & 180 \\
\hline $8 / 10 / 2009$ & 48 & -- & 270 & -- & -- & -- & -- & -- & -- \\
\hline $8 / 11 / 2009$ & 75 & -- & 125 & -- & -- & -- & -- & -- & -- \\
\hline $8 / 12 / 2009$ & 41 & -- & 360 & -- & -- & -- & -- & -- & -- \\
\hline $8 / 13 / 2009$ & 125 & -- & 90 & -- & -- & -- & -- & -- & -- \\
\hline $8 / 17 / 2009$ & 15 & 10 & 45 & 13 & 1 & 90 & 9 & 25 & 45 \\
\hline $8 / 18 / 2009$ & 1,203 & 2,420 & 90 & 3 & 7 & 90 & 20 & 32 & 90 \\
\hline $8 / 19 / 2009$ & 4 & 3 & 90 & 1 & 1 & 90 & 3 & 10 & 45 \\
\hline $8 / 20 / 2009$ & 199 & 133 & 45 & 64 & 66 & 45 & 4 & 13 & 15 \\
\hline $8 / 24 / 2009$ & 5 & -- & 90 & 1 & -- & 90 & 1 & -- & 360 \\
\hline $8 / 25 / 2009$ & 23 & -- & 210 & 1 & -- & 180 & 5 & -- & 45 \\
\hline $8 / 26 / 2009$ & 42 & -- & 90 & 194 & -- & 90 & 117 & -- & 45 \\
\hline
\end{tabular}



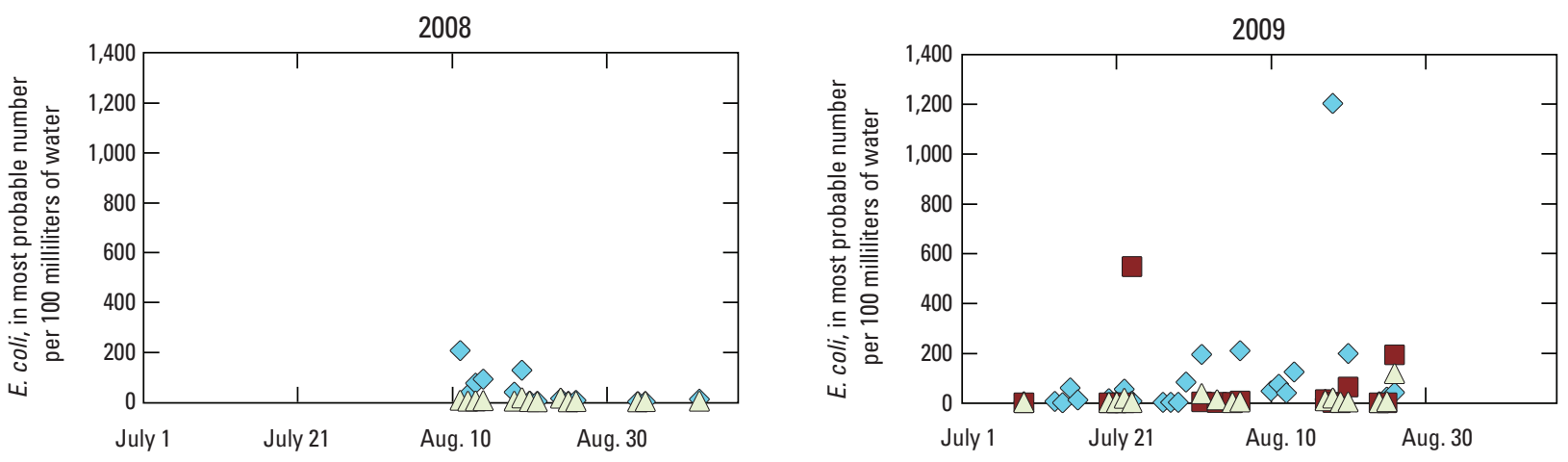

$\boldsymbol{A}$
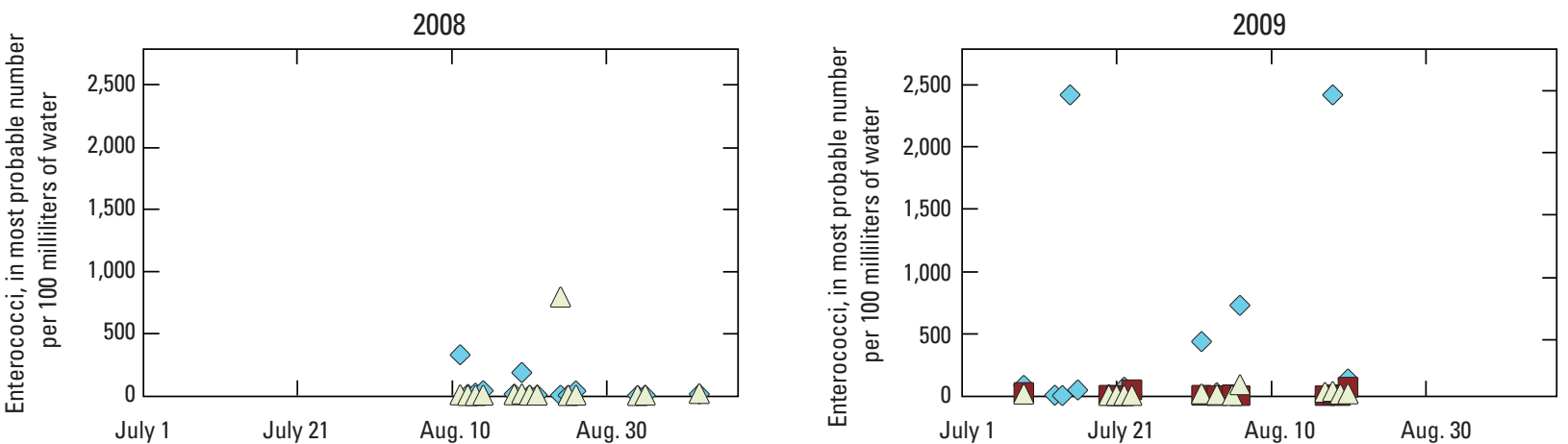

B
EXPLANATION
$\checkmark$ Beach
- Boat launch
$\triangle$ Pier

Figure 4. Time series of $A$, Escherichia coli (E. coli) and $B$, enterococci concentrations in lake water at Murphy Park Beach, 2008-9.

\section{FIB in Groundwater}

All groundwater data from 2008 and 2009 were grouped into relative piezometer location descriptions as near, middle, and far from shore (fig. 5). This approach was used because the shoreline eroded approximately $15 \mathrm{ft}$ between August 2008 and August 2009, and shallow piezometers that had originally been installed in the swash zone had to be removed and reinstalled farther upshore. Following installation, the piezometers were purged until at least $8 \mathrm{~L}$ of water had been removed from the well casing and surrounding aquifer; the typical installation resulted in $0.8 \mathrm{~L}$ of water stored within the piezometer itself. In addition to the groundwater purging, any samples with unusually high FIB concentrations that were suspected of being associated with the installation process were removed from the analysis. Such samples were limited to the first round of sampling following piezometer reinstallation and were expected to be caused by mixing and agitation of the native sand surrounding the piezometer.
The nearshore piezometers typically had the highest FIB concentrations of all piezometers and in some instances had higher FIB concentrations than the beach water (50 percent of $E$. coli samples, fig. 5C); however, the median and interquartile range in FIB concentrations in groundwater decreased rapidly with distance from the shore (fig. $5 A$ and $B$ ). This suggests that regional groundwater, or the groundwater originating hundreds of feet to a few miles inland, is likely not a major source of FIB to the beach water, although swash-zone groundwater may be a substantial source of FIB to beach water. Because regional groundwater does not appear to be a source of FIB to swash-zone groundwater, FIB in the wells nearest the lake (in the swash zone) likely originated from FIB in beach water or was washed off of sand or organic material on the shore. This process would occur as wave action spreads water inland over the shore and the water infiltrates into the soil, at which point the water and associated FIB mix with groundwater in the swash zone. This swash-zone groundwater is expected to discharge into the beach water following groundwater recharge events. 

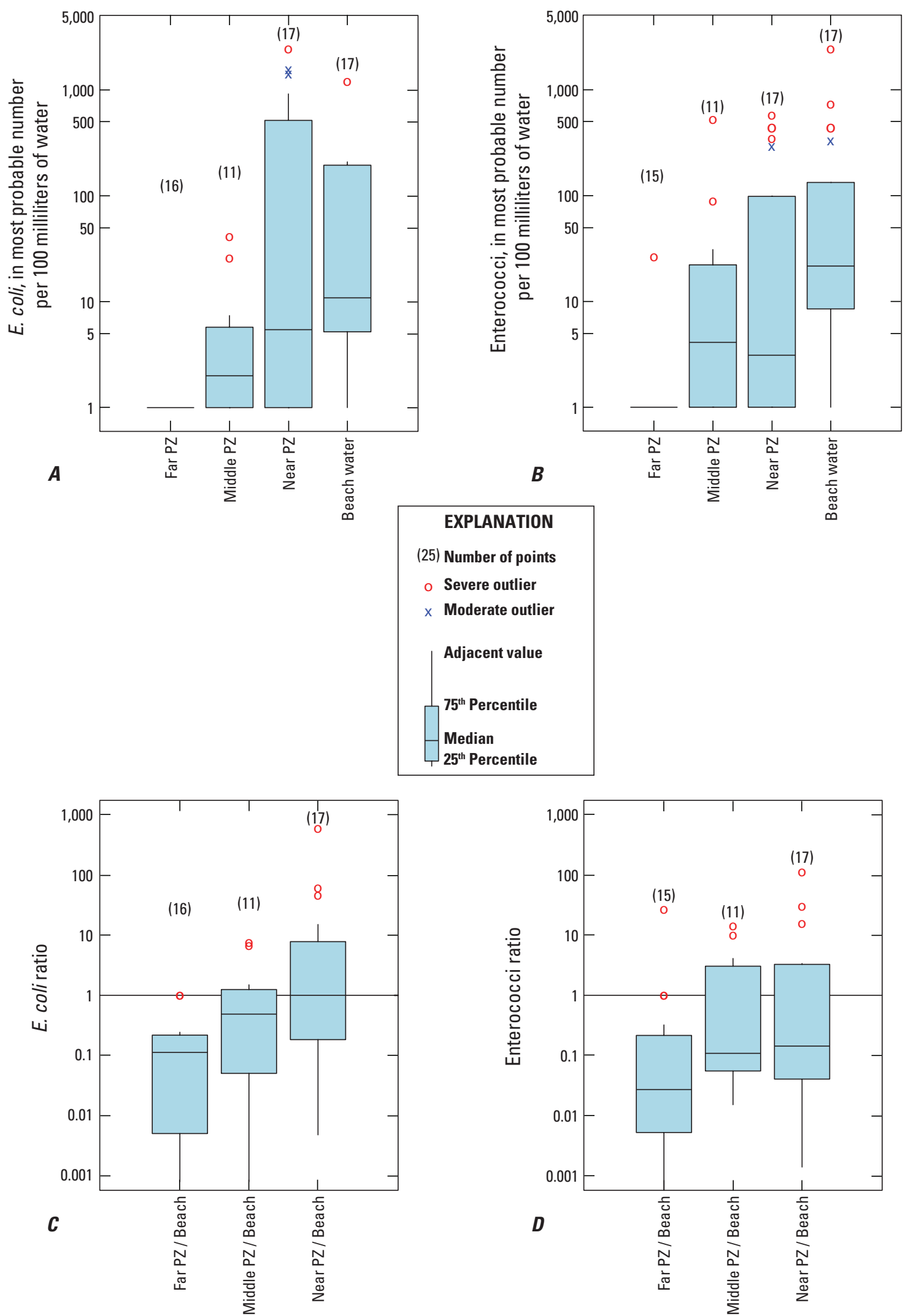

Figure 5. Boxplots of $A$, Escherichia coli (E. coli) and B, enterococci concentrations and ratios of $C$, E. coli and $D$, enterococci in groundwater for piezometer (PZ) sites at Murphy Park Beach, 2008-9. Far, Middle, and Near descriptors indicated the relative distance from the shoreline, respectively. 


\section{FIB Associated with Suspended Particulates in Lake Water}

FIB concentrations generally increased from the lowest concentrations in samples associated with suspended particulates larger than 63 microns, to larger concentrations in samples associated with suspended particulates larger than 1 micron, to the highest concentrations in the filtrate (fig. 6). The increasing FIB concentration with decreasing filter pore size suggests that fewer FIB are associated with coarsegrained suspended particulates (sand) than with fine-grained particulates. In general, it appears more FIB are present either as free-floating bacteria or attached to particles smaller than 1 micron than are attached to larger suspended particulates. This finding suggests that potential high FIB concentrations released from eroded beach sand may be dispersing directly to the water column rather than settling out with sediment. Similarly, this finding suggests that submerged sand would be an unlikely source of FIB to the water column, because it appears that FIB are not strongly bound to sand-sized particulates (see "FIB in Beach Sand" below). In general, the sum of total FIB concentration from each filter pore-size category was similar to that measured from the corresponding grab sample of beach water. Still, summations for several samples produced concentrations that were larger or smaller than the grab sample by more than an order of magnitude, highlighting the uncertainties associated with this analysis.

\section{FIB in Beach Sand}

Similar to previous findings from this region of Lake Michigan (Zehms and others, 2008), FIB concentrations associated with sand samples at Murphy Park Beach were higher in swash and upshore areas of the beach than in submerged sand samples (fig. 7). Moreover, variability in FIB concentrations was higher in the swash and upshore samples than in the submerged sand samples.

\section{FIB Associated with Cladophora Mats}

Similar to previous findings (Englebert and others, 2008; Vanden Heuvel and others, 2010), FIB concentrations in water near Cladophora mats at Murphy Park Beach span a large range of more than three orders of magnitude and decrease with distance from Cladophora mats (fig. 8). In general, FIB concentrations were highest in water samples collected within
Cladophora mats, with medians of $471 \mathrm{MPN} / 100 \mathrm{~mL}$ for E. coli and $794 \mathrm{MPN} / 100 \mathrm{~mL}$ for enterococci; intermediate in water samples adjacent to Cladophora mats, with medians of $136 \mathrm{MPN} / 100 \mathrm{~mL}$ for $E$. coli and $529 \mathrm{MPN} / 100 \mathrm{~mL}$ for enterococci; and lowest in water samples from the standard beach water sampling location, with medians of $125 \mathrm{MPN} / 100 \mathrm{~mL}$ for E. coli and 99 for and enterococci. Differences in the mean concentrations among these locations were not statistically significant due to the small sample size.

\section{Pathogen Detection in Lake Water and Groundwater}

No genes indicating the presence of $E$. coli $\mathrm{O} 157$ $\left(r f b_{0157}\right)$, Campylobacter jejuni or coli, or pathogenic Salmonella, Shigella, or Enterococcus were detected in lake water or groundwater. Of the three genes indicating potential STEC, only the eaeA gene was detected, and that only in 8 of the 44 samples tested. The eaeA gene encodes the ability to attach to intestinal cells and is considered a fundamental virulence factor for several types of pathogenic E. coli, although multiple subtypes of this gene are associated with varying disease outcomes (Trabulsi and others, 2002). In the United States, the eaeA gene is not typically considered a primary indicator of pathogenic E. coli in the absence of other virulence genes, such as the Shiga toxin genes.

The lack of detection of pathogen genes in these samples could simply be a reflection of the quality of the water at this site. As noted previously, however, samples were preserved for an extended period before DNA extraction. Although we cannot determine whether this preservation period compromised the ability to detect pathogen genes, the E. coli $16 \mathrm{~S}$ rDNA gene was detected in every sample where it would be expected, based on E. coli counts conducted at the site on the day of sampling. Thus, analysis of this internal control gene did not appear to be compromised by extended storage. 

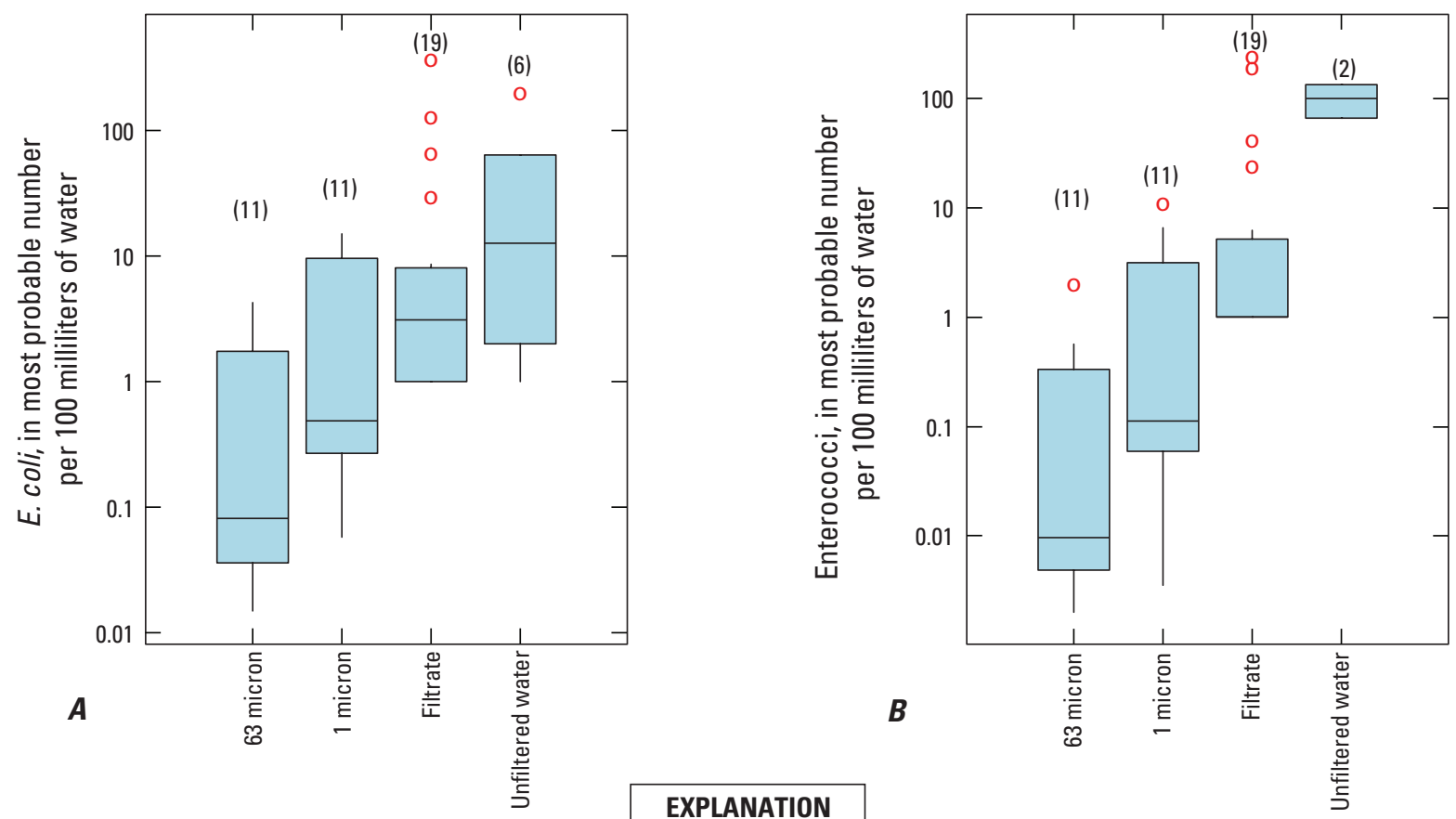

\begin{tabular}{|cl|}
\hline \multicolumn{2}{|c|}{ EXPLANATION } \\
(25) & Number of points \\
0 & Severe outlier \\
$\mathrm{x}$ & Moderate outlier \\
$\mid \begin{array}{l}\text { Adjacent value } \\
75^{\text {th }} \text { Percentile } \\
\text { Median }\end{array}$ \\
\hline $25^{\text {th }}$ Percentile
\end{tabular}
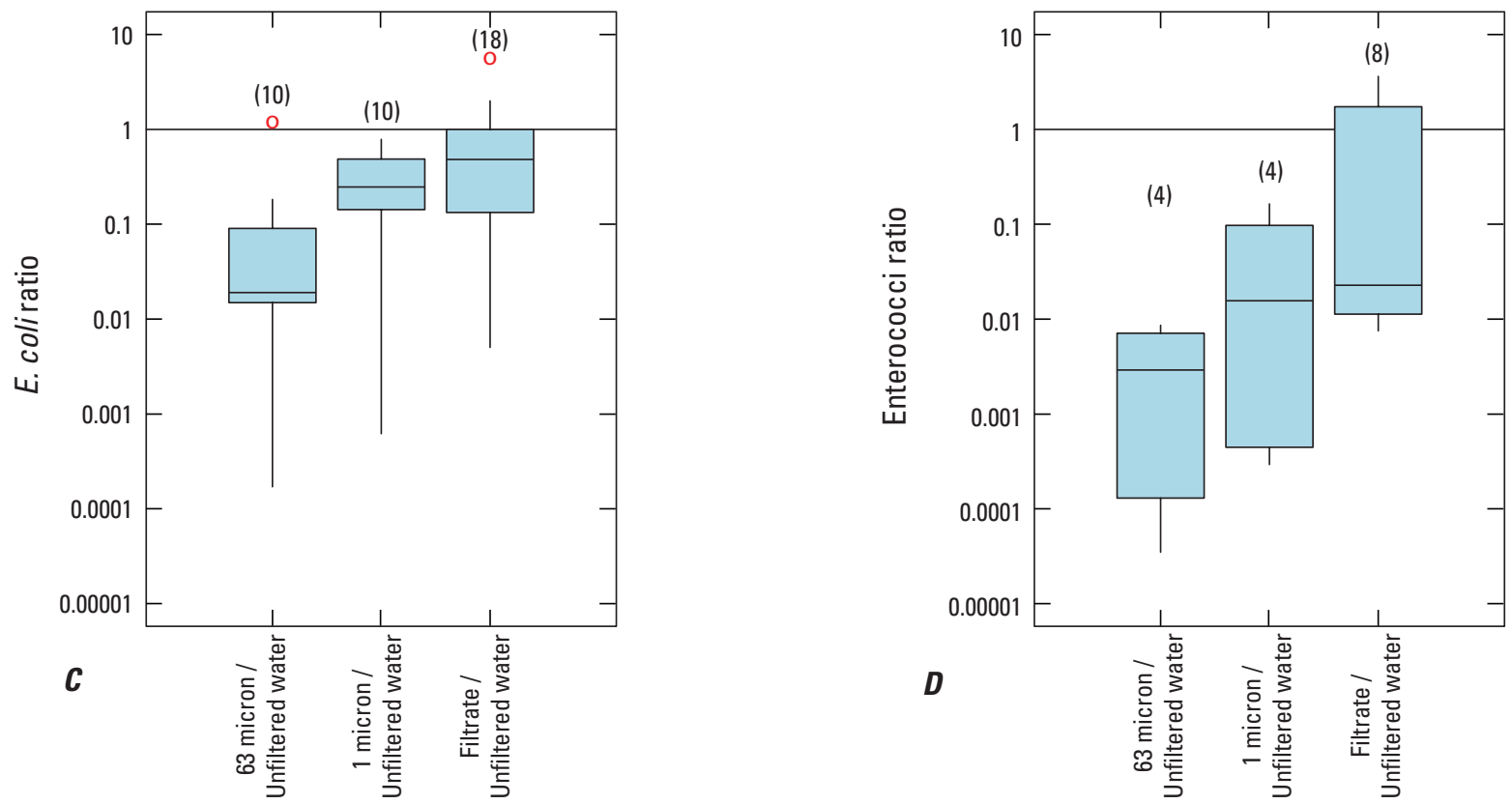

Figure 6. Boxplots of $A$, Escherichia coli (E. coli) and B, enterococci concentrations and ratios of $C, E$. coli and $D$, enterococci in samples for suspended particulates at Murphy Park Beach, 2009. 

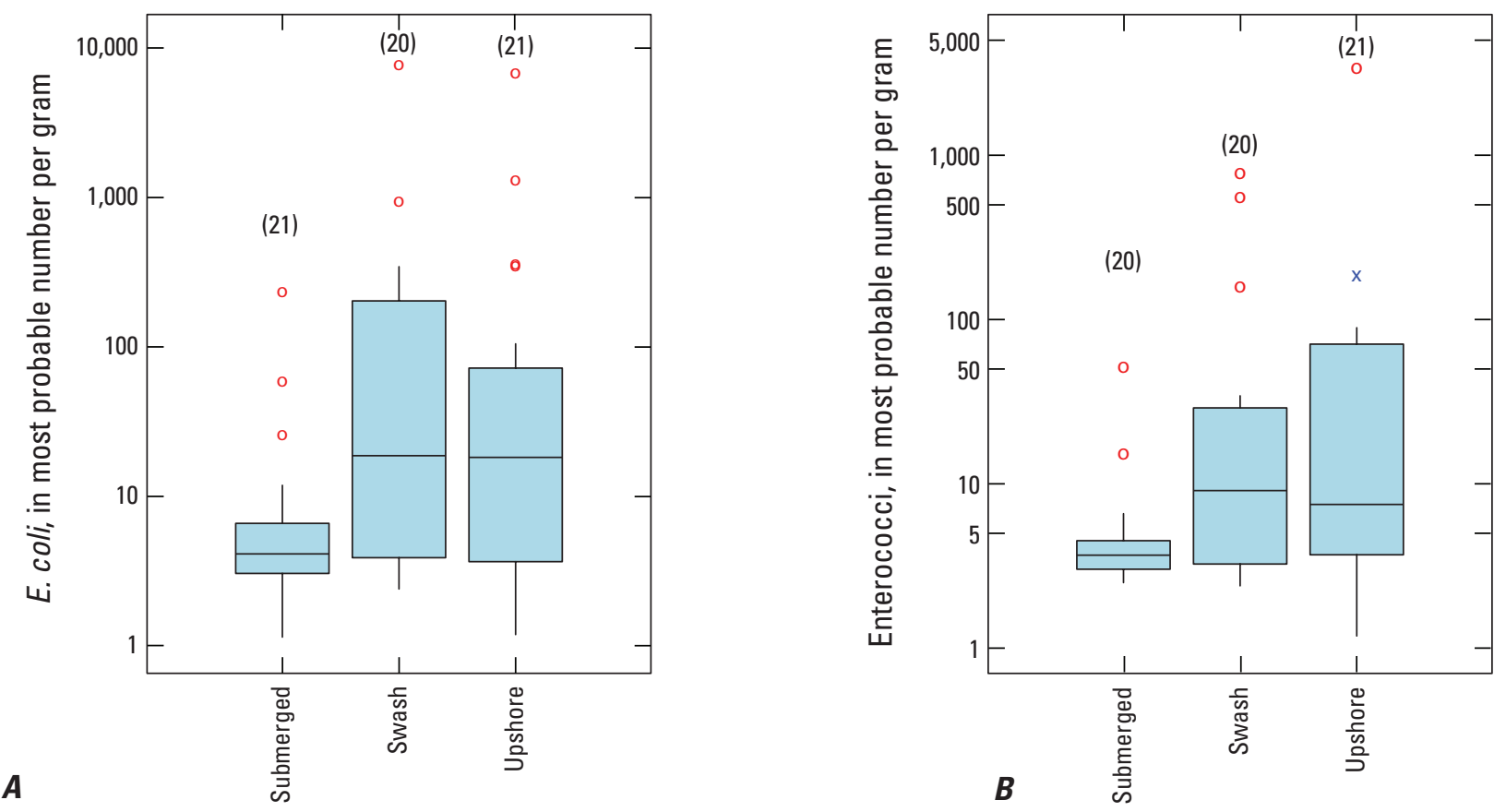

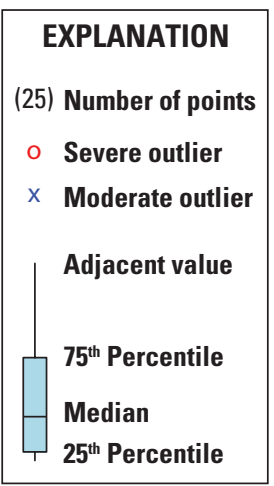

Figure 7. Boxplots of A, Escherichia coli (E. coli) and B, enterococci concentrations in sand at Murphy Park Beach, 2009. 

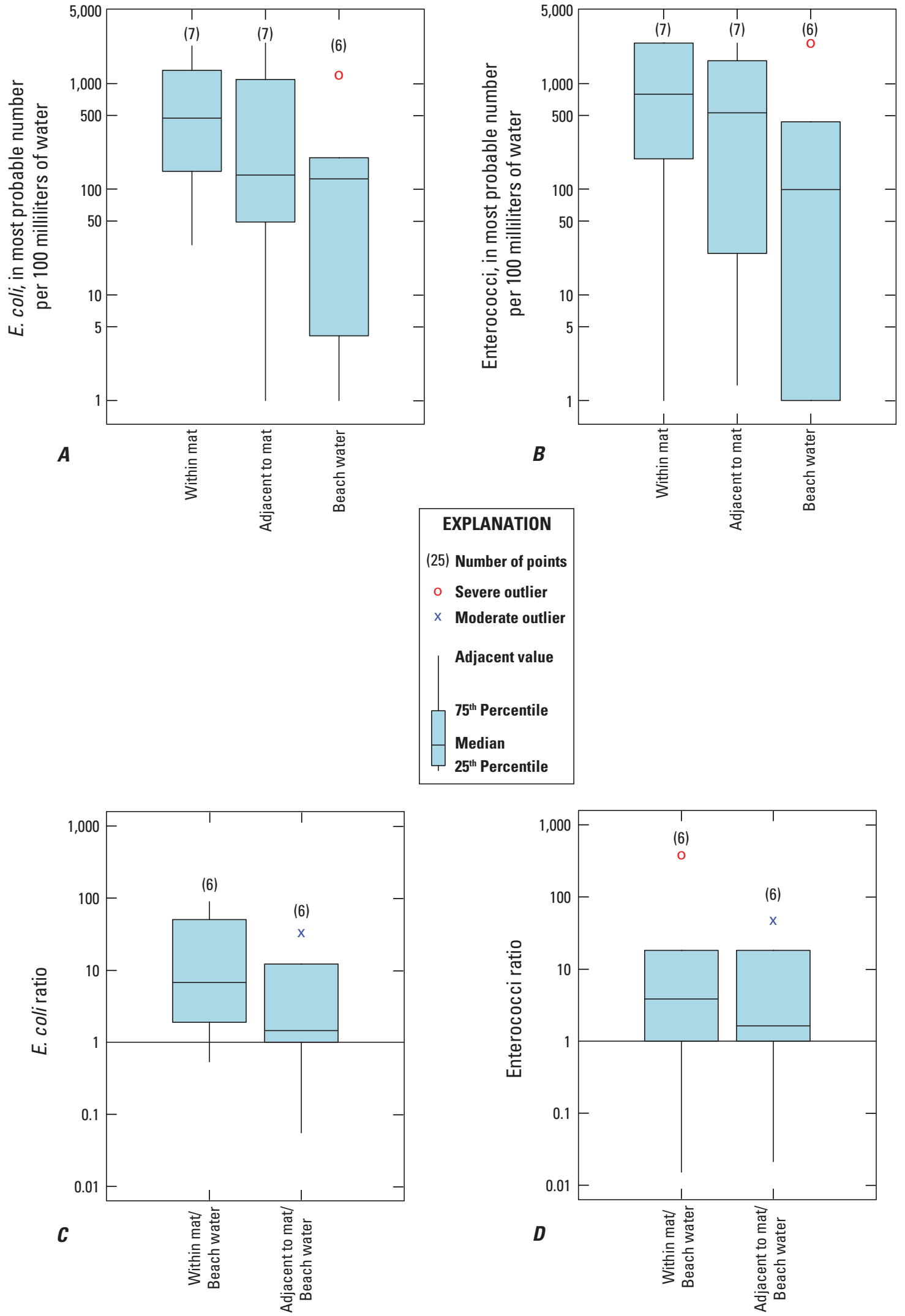

Figure 8. Boxplots of $A$, Escherichia coli (E. coli) and B, enterococci concentrations and ratios of $C$, E. coli and $D$, enterococci in water within and adjacent to Cladophora mats and in beach water at Murphy Park Beach, 2009. 


\section{Multivariate Analysis of $E$. coli Concentrations}

Results of recursive partitioning routines (level 2 analysis) using variables from the level 1 correlation analysis are as follows. The first three split variables for the two recursive partitioning analyses included hourly mean specific conductance, 10-day radar rainfall, maximum 12-hr turbidity, visibility in Sturgeon Bay, Wis., and specific conductance and wave height measured at the time of sample collection. Competitor and surrogate variables included the 96-hr median of 5-minute maximum solar radiation values, mean 6 -hr wave height, maximum 12-hr wave height, and mean 6-hr current parallel to the beach. Results of the all-subsets regression (level 3 analysis) indicated that four influential variables in explaining $E$. coli concentration were hourly mean specific conductance, turbidity measured at the time of sample collection, the most recent wind speed value from the Great Lakes Forecasting System, and wind speed at Sturgeon Bay. By use of results from levels 2 and 3, stepwise regression (level 4 analysis) indicated that the most influential variables were hourly mean specific conductance, maximum 12-hr turbidity, the most recent wind speed value from the Great Lakes Forecasting System, and visibility at Sturgeon Bay, Wis.

On the basis of this multivariate analysis, variables that appeared influential or related to $E$. coli concentration included variables indicative of storm activity (turbidity, wave height, wind speed, rainfall), exposure to sunlight (solar radiation and visibility), and specific conductance. Although all of these variables could conceivably influence $E$. coli in a setting such as Murphy Beach Park, the number of observations is not sufficient to find strong statistical relations with any individual variables except specific conductance. Specific conductance is the first split variable in both recursive partitioning analyses and the most significant variable in the stepwise regression. Specifically, the recursive partitioning routines (level 2 analyses) indicate that higher $E$. coli concentrations are correlated with specific conductance concentrations higher than 287.6 microsiemens per centimeter $(\mu \mathrm{S} / \mathrm{cm})$.

Variation in specific conductance can indicate influences from different water sources. Rain water, overland flow, and groundwater are expected to have different specific conductance values than waters of Green Bay and Murphy Park Beach. Rainfall would have lower specific conductance than lake water. Overland flow could have a large range in specific conductance depending upon the residence time and source, because quick, overland flow would have low values and large rivers or piped storm outflows could have high values. Groundwater would have substantially higher specific conductance than lake water; the average specific conductance of all groundwater samples during the study period was $700 \mu \mathrm{S} /$ $\mathrm{cm}$. Specific conductance in lake water was measured by the continuous sensor at Murphy Park Beach in 2009 and ranged over a very small interval of $283-292 \mu \mathrm{S} / \mathrm{cm}$. This small range in values indicates that large surface-water discharges in the Murphy Park Beach area likely were not an influence, in contrast to very high specific conductance values that have been observed at other Great Lakes beaches near large river or pipe outfalls (Francy and others, 2005). If rainfall influenced specific conductance, it would have had a diluting effect and been nearly immediate during and after the rainfall period, and this effect was not observed. If groundwater influenced specific conductance, there could conceivably be a substantial lag time from rainfall periods to increased groundwater discharge to the beach area due to the aquifer diffusivity, which is the ratio of transmissivity to storativity (Bredehoeft, 2011). To explore this possibility, a series of different rainfall summations from 0.5 to 40 days were used to predict daily average specific conductance as measured by the continuous sensor for the period of study in 2009; an autoregressive integrated moving average (ARIMA) time-series modeling approach was used for this analysis. Autoregressive integrated moving averaging is a class of stochastic models that is commonly applied to timeseries data to account for autocorrelation and temporal trends (nonstationarity) of the time series. The optimal relation, as measured by maximum log-likelihood, was found using a 20-day summation of rainfall, with local maxima of the loglikelihood values at 8- and 12-day rainfall summations. In all three of these cases, an autoregressive term of one, a differencing term of one (the "integration" term), and a moving average term of zero (no moving average) were optimal. The resulting model for 20-day rainfall had an $\mathrm{R}^{2}$ of 0.92 .

An 8-, 12-, or 20-day time lag for the relation of rainfall to specific conductance suggests a possible influence of groundwater discharge during this study. The time lag is due to the aquifer diffusivity, which dampens and delays the propagation of a change in hydraulic gradient (due to recharge) through the aquifer (Bredehoeft, 2011). Propagation of a relatively distinct recharge event, albeit lagged by $8-20$ days, through fracture conduits in the carbonate aquifers of Door County is reasonable given the high bulk transmissivity of the aquifer and the low storage properties of conduit flow in Door County (K.R. Bradbury, Wisconsin Geological and Natural History Survey, oral commun.).

The recursive partitioning split (level 2 analysis) of samples with specific conductance greater than $287.6 \mu \mathrm{S} /$ $\mathrm{cm}$ was examined further using the remaining explanatory variables that were identified during the multivariate analysis, which were variables used in levels 3 and 4 . A threshold of $1 \mathrm{ft}$ for 12-hr maximum wave height was identified as a secondary partitioning split for the subset of FIB samples that also had specific conductance values greater than $287.6 \mu \mathrm{S} / \mathrm{cm}$. Indeed, all five $E$. coli samples with concentrations greater than $100 \mathrm{MPN} / 100 \mathrm{~mL}$ are in the category with relatively high specific conductance and high wave height (fig. 9). Although this type of "decision tree" is not necessarily predictive of future conditions, it serves to provide valuable information about the mechanisms that influence water quality at Murphy Beach Park. 


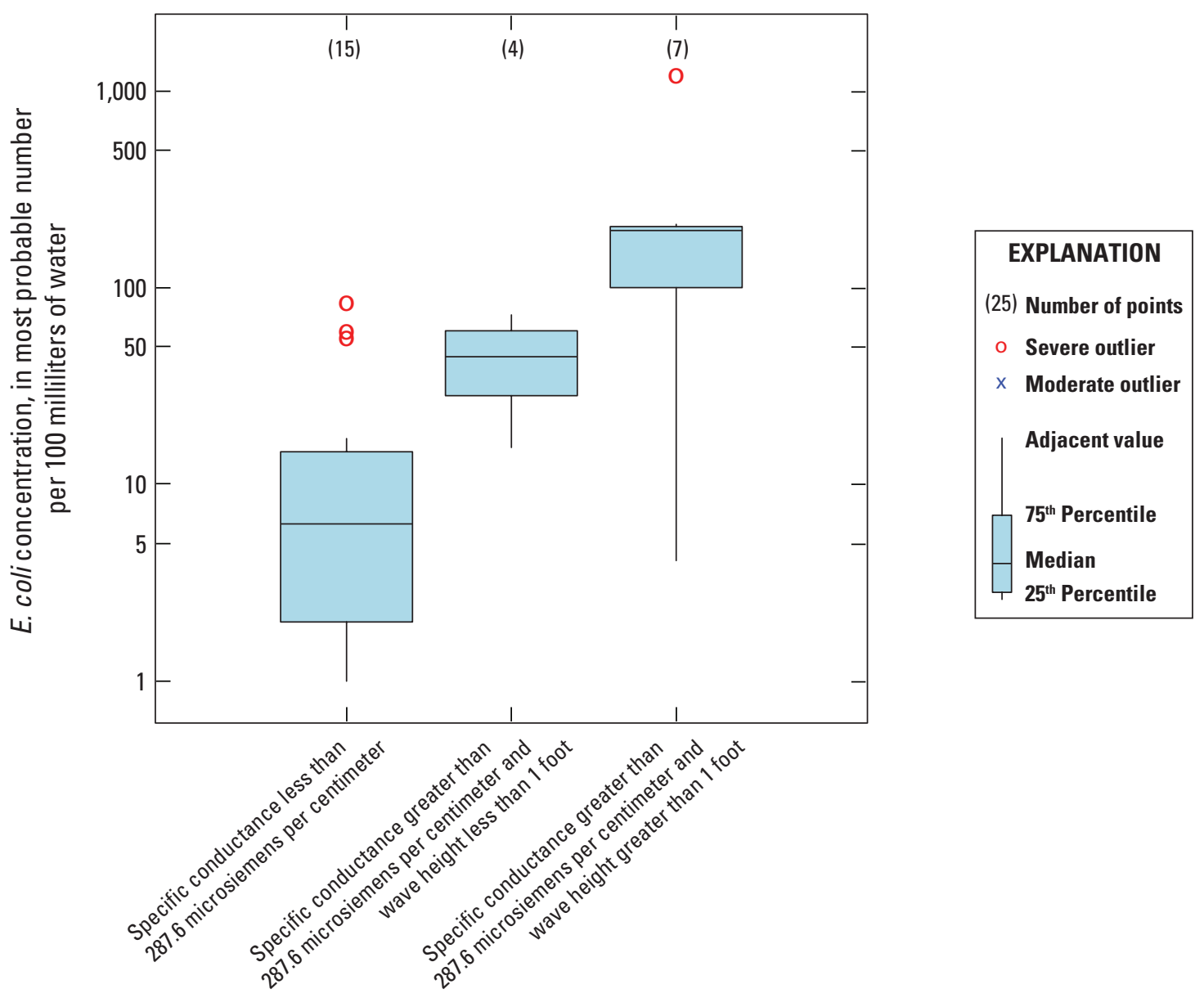

Figure 9. Escherichia coli (E. coli) concentration in beach water at Murphy Park Beach, grouped by specific conductance and wave height, 2009. 


\section{Potential Transport Mechanisms for FIB}

\section{Transport of FIB through Long-Shore Currents}

Because FIB concentrations were typically higher at the beach site than at the pier and boat launch sites, which border the beach to the northwest and south, external loading of FIB to the beach via lake water currents does not appear likely. Similarly, Kleinheinz, McDermott, Leewis, and Englebert (2006) found little indication of FIB conveyance along the periphery of beaches. Nonetheless, although FIB loading from lake water beyond the immediate swimming area is likely small, such FIB transport cannot be categorically ruled out. An evaluation of water current direction on days with high FIB concentrations outside of the beach in 2009 was used to further evaluate external loading of FIB to the beach; current direction data were not collected in 2008.

Water current direction information collected at the time of water-sample collection at all three lake water sampling sites indicates that on the day in 2009 with the highest FIB concentration outside of the beach-when the E. coli concentration was $548 \mathrm{MPN} / 100 \mathrm{~mL}$ at the boat launch on July 23, 2009 - the current direction at the boat launch and pier was toward the south (190 degrees from north) and, thus, was flowing away from the recreational beach area. On all other days in 2009 when FIB concentrations at the pier or boat launch exceeded those at the beach (as noted in "FIB in Lake Water" above and table 5), current direction at the boat launch was easterly (90 degrees from north and toward shore) and northeasterly at the pier (45 degrees from north). Current direction at the beach was easterly (toward shore) on July 23, 2009, and either easterly or northeasterly on the other dates when external FIB concentrations exceeded FIB concentrations in beach water. The portion of the shoreline where Cladophora samples were collected (fig. 2) is angled at about 16 degrees east of north. These current direction data imply that some water can circulate within the beach area, as must be the case when current direction at the beach is directed toward the beach, and that some lake water transport to the beach area is possible - though there is little evidence to suggest that lake water transport is a primary source of FIB to the beach. At the beach, the highest FIB concentrations were evident when the current was directed generally northeasterly or easterly (fig. 10A). These patterns could imply importation of FIB from Green Bay waters, or, more likely, increased erosion of beach sand due solely to waves, or to the accumulation of Cladophora mats along the beach shoreline where they can be trapped by the pier, or to a combination of beach sand erosion and Cladophora mats.
Wind directions from the nearest model grid point, provided by the National Oceanic and Atmospheric Administration Great Lakes Forecasting System (Schwab and Bedford, 1999), show that FIB concentrations were highest when wind was coming from the south to southwest (fig. 10B). This relation, though not statistically significant, may be associated with possible north-to-northeasterly oriented wave motion or from trapping of Cladophora mats along the beach and pier.

\section{Transport of FIB from Swash-Zone Groundwater}

Groundwater discharge is another possible mechanism for transporting FIB from swash-zone and upshore sand to beach water (figs. 5 and 11). Indeed, one of the strongest correlations with FIB concentrations in lake water at the beach site is the specific conductance of the lake water, which is expected to be influenced by groundwater discharge (see "Multivariate Analysis"). Moreover, the specific conductance in lake water measured in 2009 is highly correlated with weekly to multiweek precipitation levels (rho $>0.8$ between specific conductance and 12-day total rainfall), which may be an indicator of groundwater recharge and subsequent groundwater discharge. The influence of enhanced groundwater discharge on specific conductance can be extended to FIB transport as well. FIB contamination at the beach does not appear to come from the regional groundwater due to the lack of FIB in piezometers far from the beach, as described above in "Fecal Indicator Bacteria in groundwater." Instead, the relatively higher FIB concentrations in swash-zone groundwater suggest that increases in the groundwater gradient directed toward the lake (Sherrill, 1978) would induce transport of FIB in swash-zone groundwater into the beach water column. That is, FIB loading into swash-zone groundwater is likely from waves or precipitation washing FIB through the beach sand into the swash-zone groundwater reservoir. Following a regional groundwater recharge event, the hydraulic gradient at the shoreline rises, increasing the rate of swash-zone groundwater discharge, and FIB and ions associated with specific conductance, into the beach water. This idea is shown conceptually in figure 11.

The significance of FIB loading to beach water from swash-zone groundwater is difficult to evaluate and may not be fully characterized by comparing daily FIB concentrations in lake water and groundwater (fig. $5 C$ and $D$ ). Nonetheless, future studies may benefit from a dense well network and monitoring protocols to evaluate transient gradients and flow paths toward or away from the shoreline and the use of seepage meters that allow for direct sampling of discharging swash-zone groundwater. 


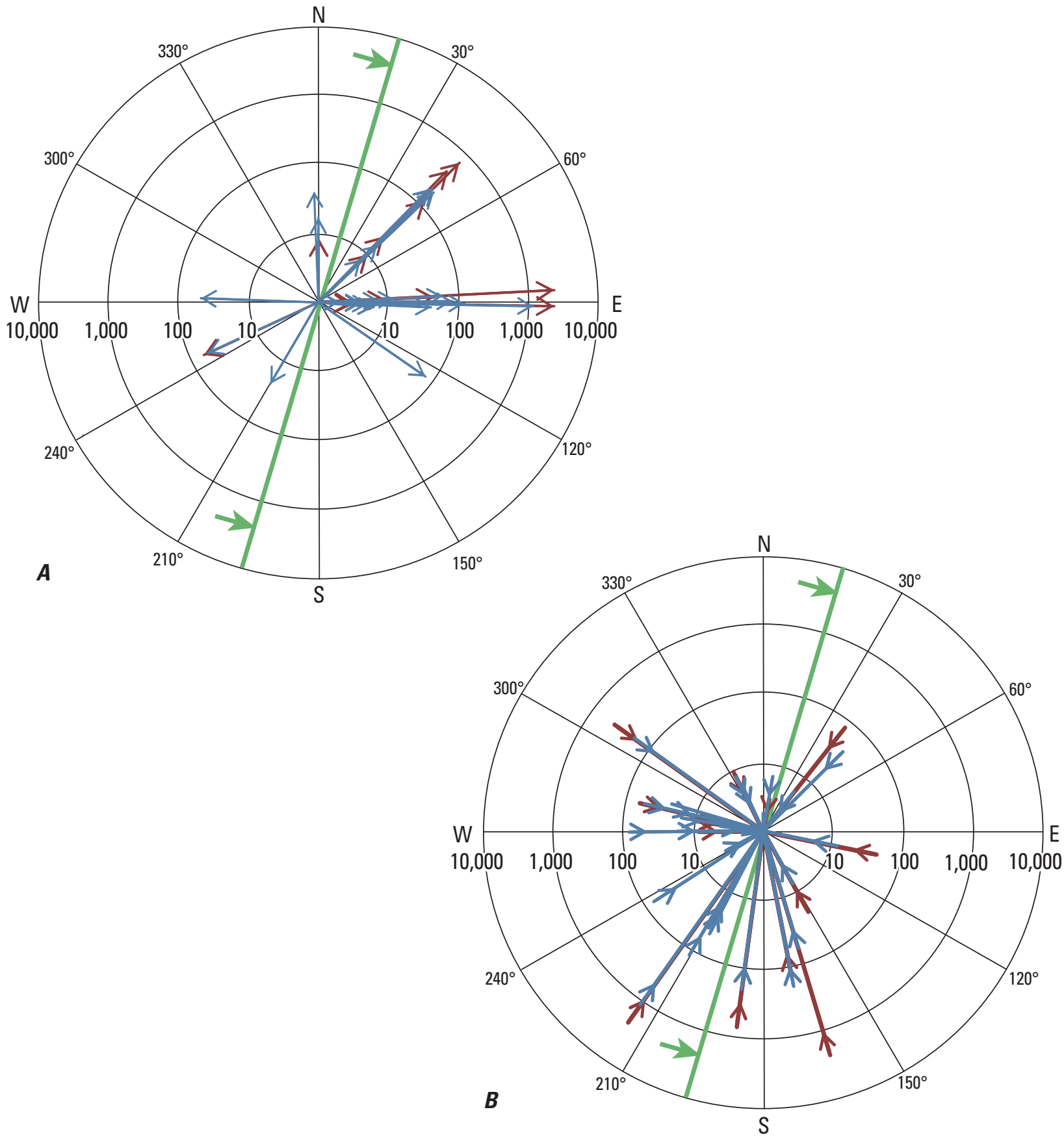

\section{EXPLANATION}

E. Coli

Enterococci

Approximate orientation of the beach shoreline at Murphy Park Beach, with arrows pointing towards shore

Figure 10. Rose diagram showing Escherichia coli (E. coli) and enterococci concentrations with respect to $A$, lake water current direction and $B$, wind direction at the time of lake water-sample collection at the beach water site at Murphy Park Beach, 2009. 


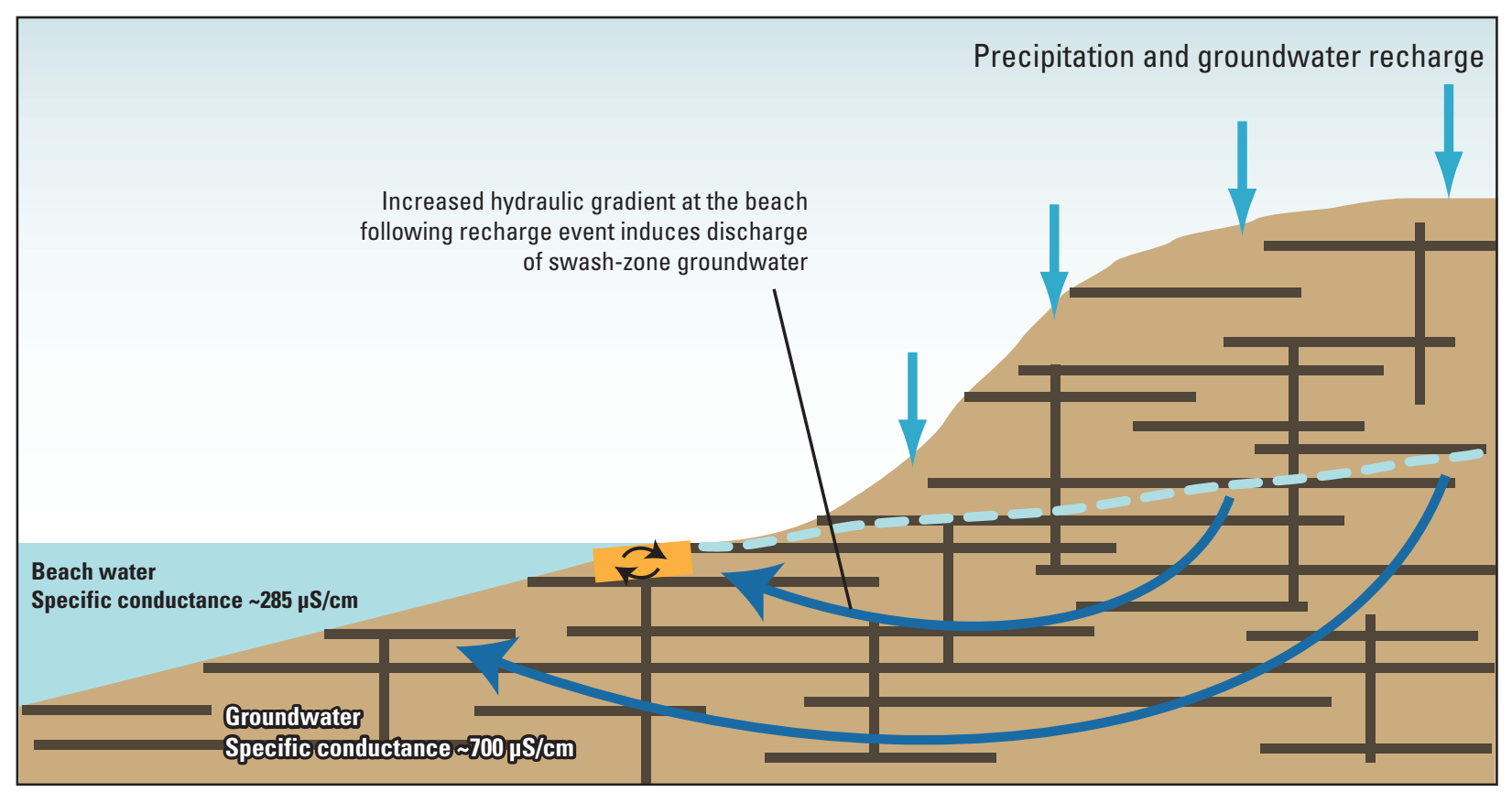

EXPLANATION

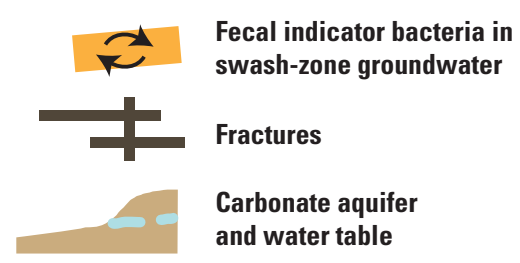

Figure 11. Schematic cross section showing groundwater recharge and discharge as a mechanism for transporting fecal indicator bacteria from the swash-zone groundwater reservoir into the lake water column.

\section{Transport of FIB from Sand and Cladophora due to Storm Activity}

Previous work by Zehms and others (2008), Englebert and others (2008), and Vanden Heuvel and others (2010) suggests that sand and Cladophora provide favorable environments for FIB growth or accumulation and may be a source of FIB to beach water. Thus, relations were evaluated to gain insight into potential FIB transport pathways among beach sand, Cladophora, and beach water. The relatively high FIB concentrations in swash-zone and upshore sand samples (fig. 7) and water samples associated with Cladophora mats (fig. 8) suggest that sand, or Cladophora, or both could be a direct source of FIB to beach water when combined with a transport mechanism.
Erosion of beach sand with direct dispersal of FIB associated with sand into the water column due to storm activity is a possible mechanism for direct transfer of FIB in swash-zone sand to beach water. Indeed, as noted earlier, approximately $15 \mathrm{ft}$ of landward migration of the shoreline owing to erosion was observed at Murphy Park Beach between September 2008 and August 2009. Moreover, FIB concentrations in beach water showed statistically significant (p-value $<0.05$ ) associations with water turbidity, wave height, current speed, wind speed, sky visibility, 24-hr precipitation, and suspended particulate concentrations. All of these ancillary metrics are indicators of storm activity that could affect beach erosion rates. These results do not constitute a direct relation between FIB concentrations in beach water and erosion of beach sand, but suggest that future work on this transport mechanism would benefit from incorporating more direct metrics of erosion and storm activity. 
Likewise, FIB concentrations associated with Cladophora mats at Murphy Park Beach are correlated with FIB concentrations in beach water (rho $=0.8$ for $E$. coli and enterococci), but lack statistical significance due to the small sample set. This relation is evident in time series plots (fig. 12), in which FIB concentrations in beach water appear to generally follow the pattern of FIB concentrations associated with Cladophora. This pattern is not as obvious for the last day that Cladophora-associated water was sampled, Aug. 20, 2009. The moderate beach water FIB concentrations of $199 \mathrm{MPN} / 100 \mathrm{~mL}$ E. coli and $133 \mathrm{MPN} / 100 \mathrm{~mL}$ enterococci on this day, compared with large concentrations on Aug. 18, 2009, of 1203 and $2420 \mathrm{MPN} / 100 \mathrm{~mL}$, may indicate that active dispersion and transport of FIB associated with Cladophora into the water column is required to produce correspondingly high FIB concentrations in beach water. Ancillary data on Aug. 18, 2009, indicate more turbulent conditions at the beach than on Aug. 20, 2009. For example, storm indicators, such as wave height, turbidity, current speed, wind speed, and suspended particulate concentrations were all substantially higher on Aug. 18, 2009, than on Aug. 20, 2009. That is, Aug. 18, 2009, had large storms, high FIB concentrations in Cladophora mats, and a high FIB concentration at the beach water sampling site. Two days later, on Aug. 20, 2009, Cladophora-associated water still had high FIB concentrations, but there was little storm activity and the beach water sample had a substantially reduced FIB concentration.
Visual evaluations of the relative amount of Cladophora present at the beach at the time of beach water sample collection illustrate that higher amounts of Cladophora appear generally associated with higher FIB concentrations in beach water (fig. 13A). The pattern does not appear to hold, however, for samples taken during periods with the greatest amount of visible Cladophora. Although this exception may appear to contradict a relation of Cladophora to higher concentrations of FIB in beach water, it may instead indicate a lack of storm activity during periods with high Cladophora abundance as estimated visually. That is, it seems reasonable to infer that a visual evaluation of the amount of Cladophora at a beach is likely to be biased by the number of large mats, which "catch" a person's eye, as opposed to the number of small and dispersed mats, even if the total Cladophora biomass were the same. Large mats of Cladophora are likely to be dispersed during periods of storm activity when wave and wind energy can also transport FIB into the larger beach water area. Indeed, evaluating FIB concentrations in the context of storm indexes suggests that $E$. coli concentrations are generally higher when Cladophora occurrence is moderate and storm indices (wave height, turbidity, current speed, wind speed) are relatively high, compared with other periods (fig. $13 B-E$ ). These relations suggest that Cladophora may be an internal source of FIB to Murphy Park Beach water during times of storm activity, although perturbation of the mats by bathers could disperse FIB to the water column immediately adjacent to the Cladophora mats. 


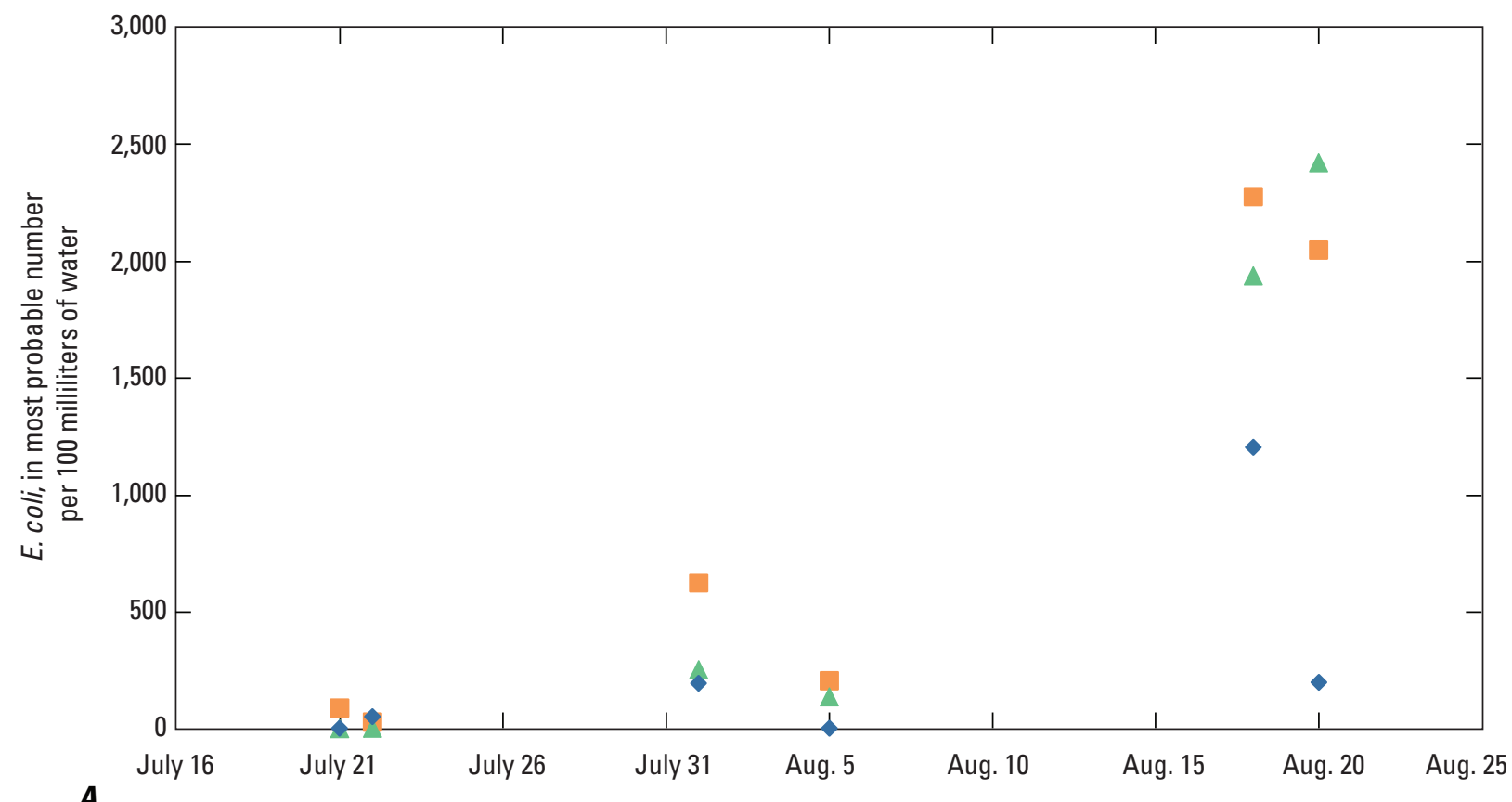

$\boldsymbol{A}$

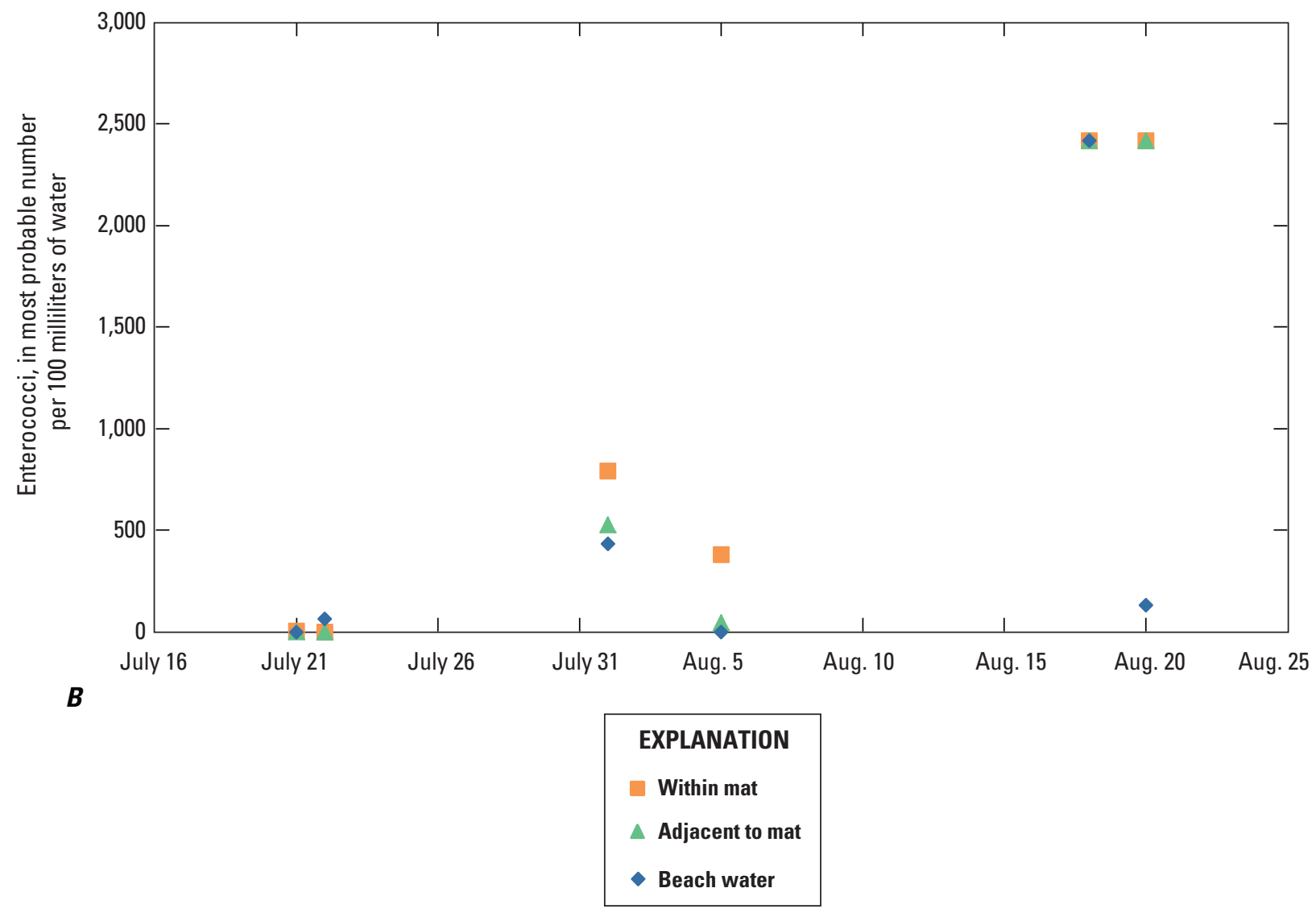

Figure 12. Graphs showing A, Escherichia coli (E. coli) and B, enterococci concentrations in beach water and in water samples collected within and adjacent to Cladophora mats at Murphy Park Beach, 2009. 

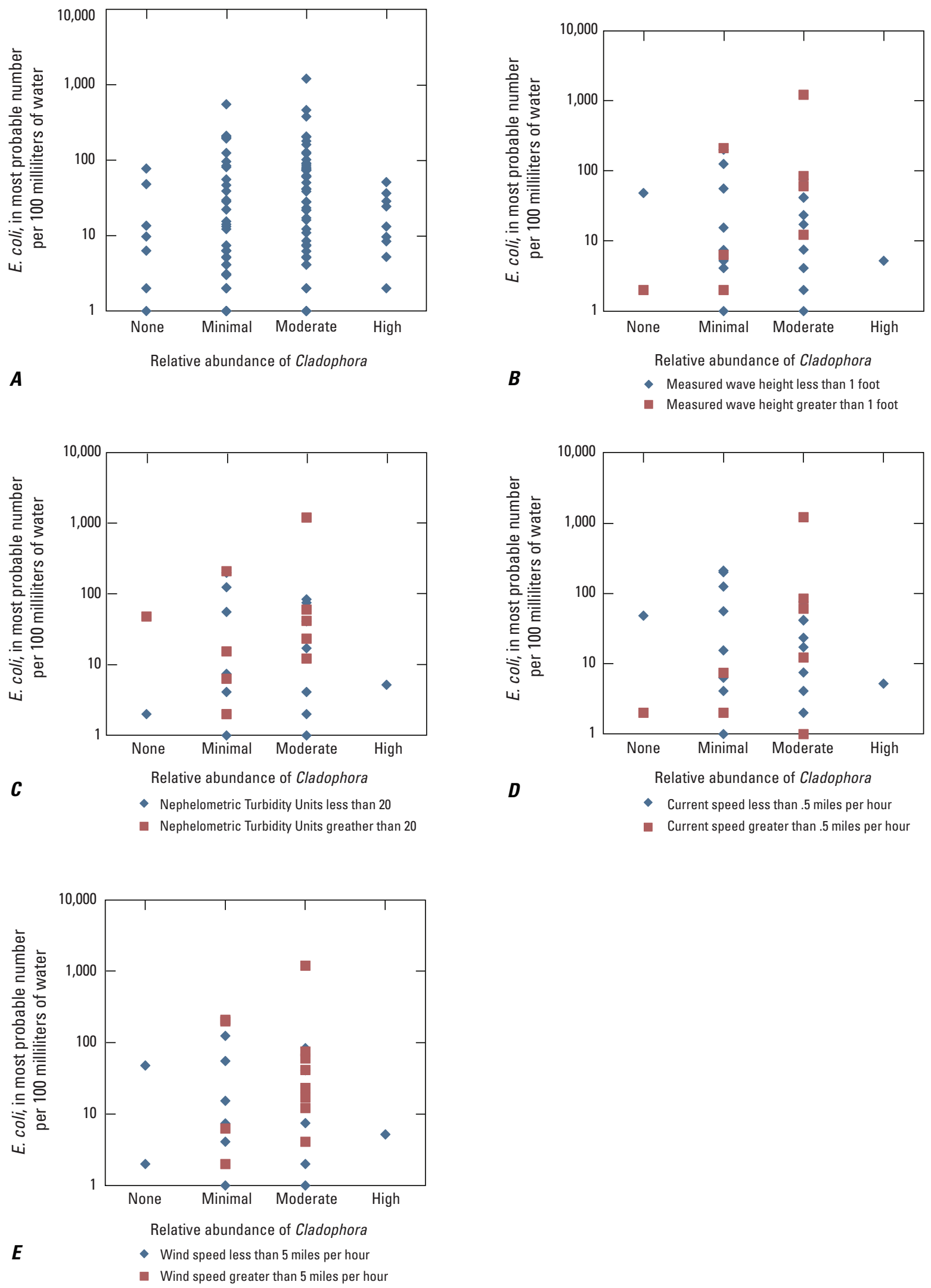

Figure 13. Escherichia coli (E. coli) concentrations associated with relative abundance of Cladophora at the time of sampling $A$, for the 2008-9 study period and for 2009 categorized by $B$, wave height, $C$, turbidity, $D$, current speed, and $E$, wind speed at the beach water site, Murphy Park Beach. 


\section{Summary}

Several potential sources of fecal indicator bacteria (FIB) to beach water at Murphy Park Beach in Door County, Wis., were evaluated by the U.S. Geological Survey, in collaboration with the Door County Soil and Water Conservation Department and the University of Wisconsin-Oshkosh. Primary sources of FIB appear to be internal to the beach rather than external FIB sources such as rivers, sewer outfalls, and industrial discharges, which are common FIB sources at other Great Lakes beaches. Three likely sources of FIB to the water column are FIB associated with sand, swash-zone groundwater, and Cladophora mats. The modest correlations between FIB concentrations in these potential source reservoirs and FIB concentrations at the beach water sampling site illustrate the importance of evaluating transport mechanisms between the sources and the water column. Likely mechanisms for transport and dispersion appear to include (1) increased discharge of swash-zone groundwater due to regional groundwater recharge and increased hydraulic gradients, and (2) erosion of sand or agitation of Cladophora mats, or both, due to storm activity, as interpreted from storm indicators such as turbidity, wave height, current speed, wind speed, sky visibility, 24-hour precipitation, and suspended particulate concentration. FIB concentrations in beach water had a statistically significant relation with these storm indicators. Because there is relatively little apparent external loading of FIB to this beach, understanding the dynamic interactions between sources of FIB from sand, swash-zone groundwater, and Cladophora with groundwater and storm transport mechanisms is important for improved predictions of beach closure due to FIB in beach water.

\section{References Cited}

Alexander, E.C., Green, J.A., Alexander, S.C., 2008, Plum Bottom closed depression groundwater trace final report: Door County Soil and Water Conservation Department, 13 p., accessed on July 13, 2011, at http://map.co.door. wi.us/swcd/Plum\%20Bottom\%20Groundwater\%20 Trace\%20Final\%20Report\%20Jan\%202008.pdf.

Baylis, C.L., MacPhee, S., Martin, K.W., Humphrey, T.J., Betts, R.P., 2000, Comparison of three enrichment media for the isolation of Campylobacter spp. from foods: Journal of Applied Microbiology, v. 89, p. 884-891.

Bredehoeft, J.D., 2011, Monitoring regional groundwater extraction-The problem: Ground Water, v. 49, no. 6, p. 808-814.
Byappanahalli, M.N., Shively, D.A., Nevers, M.B., Sadowsky, M.J., and Whitman, R.L., 2003, Growth and survival of Escherichia coli and enterococci populations in the macroalga Cladophora (Chlorophyta): FEMS Microbiology Ecology, v. 46, no. 2, p. 203-211.

Chiu, C., and Ou, J.T., 1996, Rapid identification of Salmonella serovars in feces by specific detection in virulence genes, inv $A$ and $s p v C$, by an enrichment broth culture-multiplex PCR combination assay: Journal of Clinical Microbiology, v. 34, p. 2619-2622.

Chomczynski, P., and Rymaszewski, M., 2006, Alkaline polyethylene glycol-based method for direct PCR from bacteria, eukaryotic tissue samples, and whole blood: BioTechniques, v. 40, p. $454-458$.

De'Ath, G., and Fabricius, K.E., 2000, Classification and regression trees-A powerful yet simple technique for ecological data analysis: Ecology, v. 81, no. 11, p. 3178-3192.

Door County Soil and Water Conservation Department, 2008, Door County beach contamination source identification final report 2006-2007: 93 p., accessed on Sept. 15, 2011, at http://map.co.door.wi.us/swcd/Beach\%20 Contamination $\% 20$ Source $\% 20$ Identification $\% 20$ Final $\% 20$ Report.pdf.

Dufour, A.P., 1984, Health effects criteria for fresh recreational waters: U.S. Environmental Protection Agency, EPA-600/I-84-004, 33 p.

Duris, J.W., Haack, S.K., and Fogarty, L.R., 2009, Gene and antigen markers of Shiga toxin-producing E. coli from Michigan and Indiana river water-Occurrence and relation to recreational water quality criteria: Journal of Environmental Quality, v. 38, p. 1878-1886.

Eaton, A.D., Clesceri, L.S., Rice, E.W., and Greenberg, A.E., eds., 2005, Standard methods for the examination of water and wastewater ( $21^{\text {st }}$ ed.): Washington D.C., American Public Health Association, American Water Works Association, and Water Pollution Control Federation, p. 9-1 to 9-125.

Englebert, E.T., McDermott, C.M., and Kleinheinz, G.T., 2008, Effects of the nuisance algae, Cladophora, on Escherichia coli at recreational beaches in Wisconsin: Science of the Total Environment, v. 404, no. 1, p. 10-17.

Fleisher, J.M., Flemming, L.E., Solo-Gabriele, H.M., Kish, J.K., Sinigalliano, C.D., Plano, L., Elmir, S.M., Wang, J.D., Withum, K., Hibata, T., Gidley, M.L., Abdelzaher, A., He, G., Ortega, C., Zhu, X., Wright, M., Hollenbeck, J., and Backer, L.C., 2010, The BEACHES study-Health effects and exposures from non-point source microbial contaminants in subtropical recreational marine waters: International Journal of Epidemiology, v. 39, p. 1291-1298. 
Francy, D.S., Struffolino, P., Brady, A.M.G., and Dwyer, D.F., 2005, A spatial, multivariable approach for identifying proximate sources of Escherichia coli to Maumee Bay, Lake Erie, Ohio: U.S. Geological Survey Open-File Report 2005-1386, $20 \mathrm{p}$.

Haack, S.K., Duris, J.W., Fogarty, L.R., Kolpin, D.W., Focazio, M.J., Furlong, E.T., and Meyer, M.T., 2009, Comparing wastewater chemicals, indicator bacteria concentrations, and bacterial pathogen genes as fecal pollution indicators: Journal of Environmental Quality, v. 38, p. 248-258.

Inglis, G.D. and Kalischuk, L.D., 2003, Use of PCR for direct detection of Campylobacter species in bovine feces: Applied and Environmental Microbiology, v. 69, p. 34353447.

Islam, M.S., Hasan, M.K., Miah, M.A., Sur, G.C., Felsenstein, A., Venkatesan, M., Sack, R.B., and Albert, M.J., 1993, Use of the polymerase chain reaction and fluorescent-antibody methods for detection of viable but nonculturable Shigella dysenteriae type 1 in laboratory microcosms: Applied and Environmental Microbiology, v. 59, p. 536-540.

Kleinheinz, G.T., McDermott, C.M., Hughes, S., Brown, A., 2009, Effects of rainfall on E. coli concentrations at Door County, Wisconsin beaches: International Journal of Microbiology, v. 2009, article ID 876050, 9 p., accessed at $h t t p: / /$ dx.doi.org/10.1155/2009/876050.

Kleinheinz, G.T., McDermott, C.M., and Chomeau, V., 2006, Evaluation of avian waste and bird counts as predicators of Escherichia coli contamination at Door County, Wisconsin beaches: Journal of Great Lakes Research, v. 32, p. 117123.

Kleinheinz, G.T., McDermott, C.M., Leewis, M.C., and Englebert, E., 2006, Influence of sampling depth on Escherichia coli concentrations in beach monitoring: Water Research, v. 40 , p. $3831-3837$.

Lee, C.M., Lin, T.Y., Lin, C., Kohbodi, G.A., Bhatt, A., Lee, R., and Jay, J.A., 2006, Persistence of fecal indicator bacteria in Santa Monica Bay beach sediments: Water Research, v. 40, p. 2593-2602.

R Development Core Team, 2011, R-A language and environment for statistical computing, accessed on Sept. 15, 2011, at http://cran.r-project.org/manuals.html.

Schwab, D.J., and Bedford, K.W., 1999, The Great Lakes Forecasting System, in Mooers, C.N.K., ed., Coastal ocean prediction, coastal and estuarine studies: Washington, D.C., American Geophysical Union, v. 56, p. 157-173.
Sherrill, M.G., 1978, Geology and ground water in Door County, Wisconsin, with emphasis on contamination potential in the Silurian dolomite: U.S. Geological Survey WaterSupply Paper 2047, 43 p.

Trabulsi, L.R., Keller, R., and Gomes, T.A.T, 2002, Typical and atypical enteropathogenic Escherichia coli: Emerging Infectious Diseases, v. 8, p. 508-512.

U.S. Department of Agriculture, 2008, National Agriculture Imagery Program (NAIP) Information Sheet, accessed on August 23, 2011, at $h t t p: / / w w w . f s a . u s d a . g o v / I n t e r n e t / F S A$ File/naip_2007_infosheetpdf.pdf.

U.S. Environmental Protection Agency, 2000, Improved enumeration methods for recreational water quality indicators-Enterococci and Escherichia coli: EPA 821-R-97004, $53 \mathrm{p}$.

U.S. Environmental Protection Agency, 2004, Quality assurance/quality control guidance for laboratories performing PCR analysis on environmental samples: EPA 815-B-04001, $57 \mathrm{p}$.

U.S. Environmental Protection Agency, 2006, Method 1600Enterococci in water by membrane filtration using membrane-Enterococcus Indoxyl-b-D-Glucoside agar (mEI): Washington, D.C., EPA/821/R-06/009, 42 p.

Vanden Heuvel, A., McDermott, C., Pillsbury, R., Sandrin, T., Kinzelman, J., Ferguson, J., Sadowsky, M., Byappanahalli, M., Whitman, R., and Kleinheinz, G.T., 2010, The green alga, Cladophora, promotes Escherichia coli growth and contamination of recreational waters in Lake Michigan: Journal of Environmental Quality, v. 39, no. 1, p. 333-344.

Vassiliadis, P., Trichopoulos, D., Kalandidi, A., and Xirouchaki, E., 1978, Isolation of salmonellae from sewage with a new procedure of enrichment: Journal of Applied Bacteriology, v. 44, p. 233-239.

Wade, T.J., Calderon, R.L., Sams, E., Beach, M., Brenner, K.P., Williams, A.H., and Dufour, A.P., 2006, Rapidly measured indicators of recreational water quality are predictive of swimming-associated gastrointestinal illness: Environmental Health Perspectives, v. 114, no. 1, p. 24-28.

Zehms, T.T., McDermott, C.M., and Kleinheinz, G.T., 2008, Microbial concentrations in sand and their effect on beach water in Door County, Wisconsin: Journal of Great Lakes Research, v. 34, p. 524-534. 




$$
\begin{aligned}
& \mathbb{8} \\
& \frac{8}{8} \\
& \hline
\end{aligned}
$$

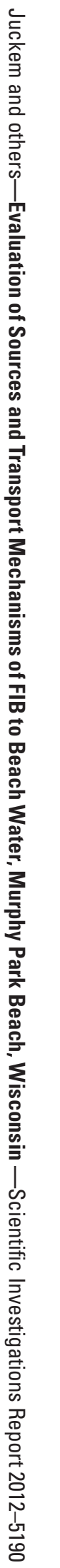

